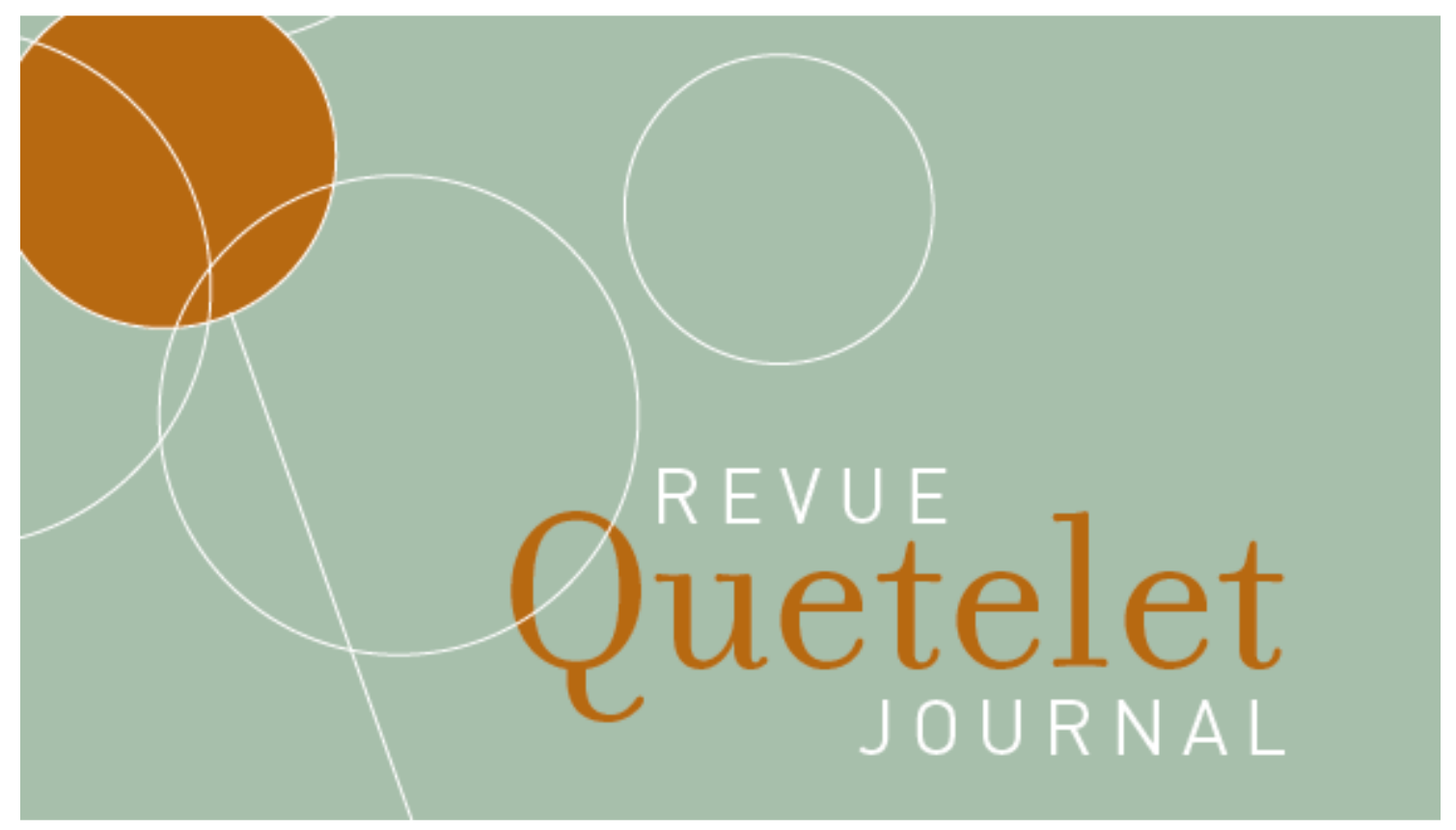

Vol. 5, $\mathrm{n}^{\circ} 2$, octobre 2017, pp. 69-114

DOI : $10.14428 /$ rqj2017.05.02.03

ISSN: 20349378

\title{
The ageing of populations in Belgium: Current situation and perspectives
}

\author{
Mélanie Bourguignon \\ Jean-Paul Sanderson \\ Catherine Gourbin
}

C2017 Mélanie Bourguignon, Jean-Paul Sanderson, Catherine Gourbin

This work is licensed under a Creative Commons Attribution-NonCommercial 4.0 International License. You can share, adapt the material for non-commercial purposes provided that you give appropriate credit and indicate if changes were made. For details see https://creativecommons.org/licenses/by-nc/4.0/

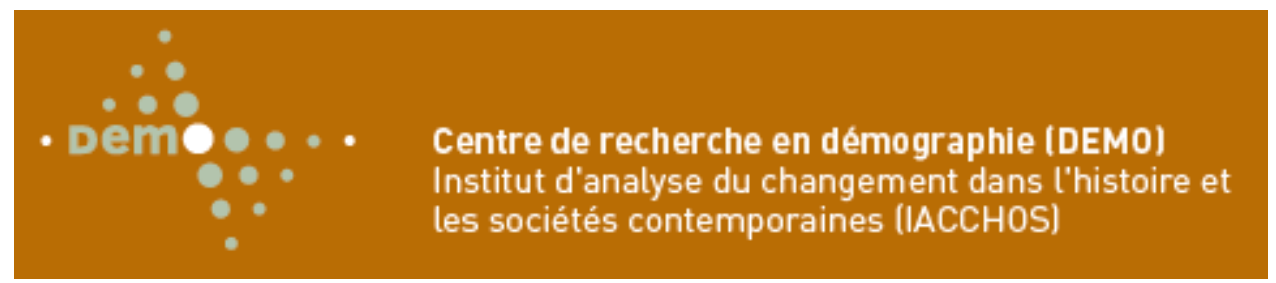





\title{
The ageing of populations in Belgium: Current situation and perspectives
}

\author{
MÉLANIE BOURGUIGNON ${ }^{1}$ \\ JEAN-PAUL SANDERSON ${ }^{1}$ \\ CATHERINE GOURBIN ${ }^{1}$
}

\begin{abstract}
Résumé
Depuis quelques décennies, les pays occidentaux font face au vieillissement de leur population, résultat du processus de transition démographique. Cet article traite du vieillissement des populations et des défis qu'il implique, essentiellement du point de vue du démographe. La première section est centrée sur l'évolution démographique du vieillissement depuis les années 1970 et les particularités de la Belgique en tant que pays européen ainsi que ses spécificités régionales sont étudiées. L’augmentation de la population âgée de 60 ans et plus, et plus particulièrement celle des 80 ans et plus, s'accompagne de modifications des profils sociodémographiques des populations. Dans la deuxième section, l'accent est mis sur les conséquences du vieillissement en termes de santé, notamment à travers l'indicateur, aujourd'hui fréquemment utilisé, d'espérance de vie en bonne santé. Avec le report des décès à des âges de plus en plus élevés, la probabilité de survenue de problèmes de santé a augmenté. Dans ce cadre, si les aidants professionnels sont indispensables dans la prise en charge à domicile des personnes âgées à domicile, cet article s'est intéressé plus particulièrement aux aidants proches qui jouent un rôle primordial dans la possibilité du maintien à domicile des personnes âgées. Une troisième et dernière section est consacrée aux conséquences socioéconomiques du vieillissement des populations, avec une réflexion autour de la "durabilité» du système de sécurité sociale tel qu'il est organisé aujourd'hui en Belgique. Lorsque cela s'avère possible, des comparaisons sont réalisées avec les situations observées dans d'autres pays européens.
\end{abstract}

\section{Mots-clés}

Vieillissement démographique, Belgique, Europe, espérance de vie en bonne santé, système de pension.

1. Centre for Demographic Research, Université catholique de Louvain (UCL), Louvain-la-Neuve, Belgium. 


\begin{abstract}
For many decades now, population ageing is observed in every Western countries, as the result of the demographic transition. This article focuses on these issues through the particular lens of the demographer. The first section is focused on the evolution of ageing since 1970, situating Belgium in its wider context as a European nation and analysing spatial differences within Belgium according to standard demographic indicators. The increase in the population over 60 and especially over 80 comes along with a transformation in the population profile. In the second section we look at consequences of ageing in terms of health through an indicator that has now become standard, that of healthy life expectancy. With death taking place at ever older ages, the chance of experiencing health problems has also risen. If today's health-care systems are vitally important in helping older people remain at home for longer, we have focused on the role of the family caregiver, a vital facet of health-care systems for the old. Finally, the third section is devoted to the socioeconomic consequences of demographic ageing, especially in terms of the resilience of the social security system. Where possible, we draw comparisons with the situation in other European countries.
\end{abstract}

\title{
Keywords
}

Population ageing, Belgium, Europe, Healthy life expectancy, Pension system.

\section{Introduction}

For many decades now, scientists have been warning policy-makers about the ageing of the population and its socioeconomic consequences (Loriaux et al., 1990). This ageing, observed in every Western country, is the result of the demographic transition - which in Belgium took place in the nineteenth century - which saw a regime of high fertility and mortality rates transformed into one of low fertility and mortality rates.

The number of children per woman thus plunged from 4.47 in 1866 to 3.04 in 1910 (Festy, 1979; Brée et al., 2016), 1.61 in 1991 and 1.87 in 2010 (Costa et al., 2010) (Figure 1). Fewer births has meant that the relative proportion of young people has gradually weakened, leading to a natural increase in the proportion of older people. This is known as ageing from the bottom, in reference to the narrowing of the bottom of the population pyramid. At the same time, life expectancy at birth has increased from 40 years in 1830 to 84 years for women and 79 for men in 
$2016,{ }^{2}$ thus explaining the reduction in the mortality rate for all ages (Figure 2). This dynamic has resulted in a phenomenon of ageing from the top (with more and more people surviving to old age). These two changes taken together have led to an overall ageing of the population (Eggerickx et al., 2011) and to a smoothing of the age structure, with the vagaries of mortality affecting populations to a lesser and lesser degree.

FIGURE 1 Evolution of fertility in Belgium, 1805-2015

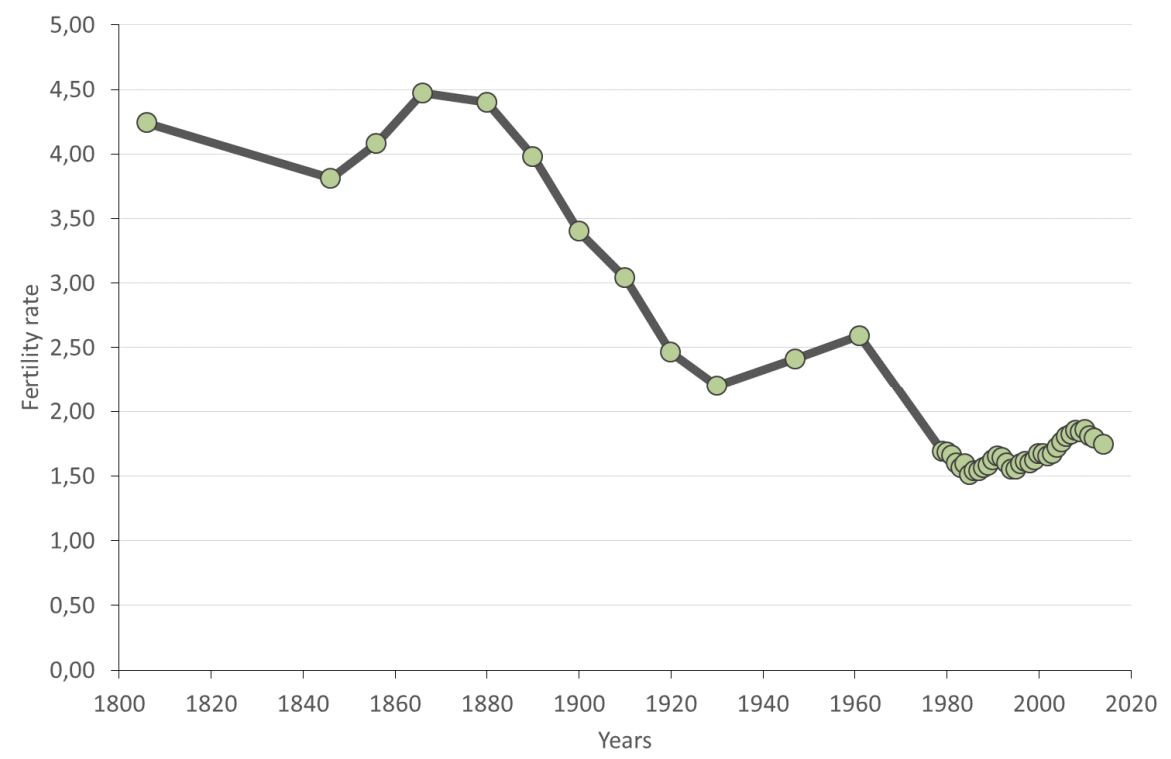

Source: Festy, 1979; Costa et al., 2010; Brée et al., 2016.

These changes have been particularly noticeable over the past 45 years and can be readily discerned in population pyramids (Figures 3 and 4). In 1970 , the pyramid still somewhat resembled a geometric pyramid, with a relatively wide base narrowing upwards. At that time, $13 \%$ of the population was aged 65 years or more and only $2 \% 80$ or more. With the decrease in fertility, the bottom has shrunk and is narrowing, while the generations at the top are more numerous due to the increase in longevity. For 2015, ageing is more obvious. The structure is shaped rather like a haystack, with $17 \%$ of the population now 65 years of age or more and $5 \% 80$ or more. The base is not as wide and contains fewer people than do the various age groups between 35 and 59 .

2. https://statbel.fgov.be/fr/themes/population/mortalite/tables-de-mortalite-et-esperance-de-vie. 
FIGURE 2 Evolution of life expectancy at birth in Belgium, 1830-2015

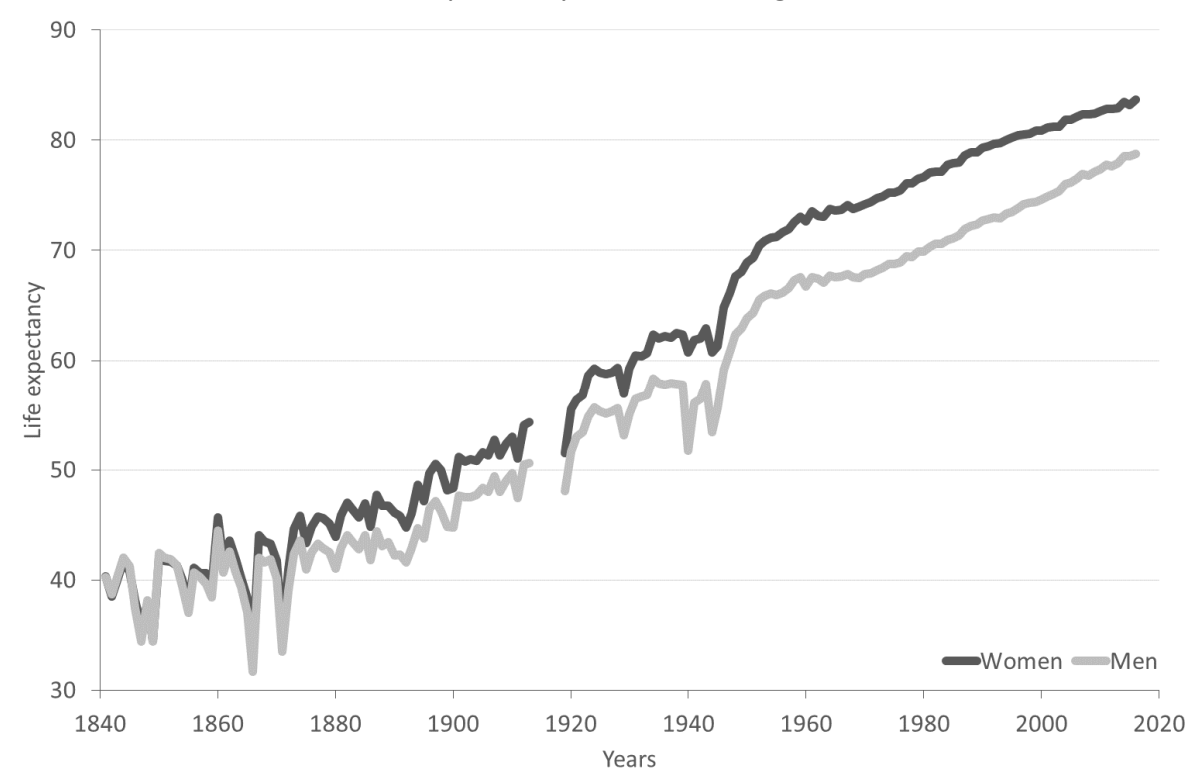

Source: Human Mortality Database.

This change in the demographic profile impacts upon individual people as well as states. At the individual level, an increasing life expectancy raises issues about the state of health of older people (Lannoye, Lypszic, 2000) and how life unfolds after the working years are over. At the national level, the maintenance of social security systems in the face of change are a crucial issue that has been acknowledged for many years (Devolder, Maréchal, 2007; Vandenberghe, 2010).

This article focuses on these issues through the particular lens of the demographer. The aim is not to repeat the ideas of economists, sociologists, medical doctors, etc. on ageing but rather to examine it as a demographic issue. To achieve this we will set the stage by giving an overview of the evolution of ageing since 1970, situating Belgium in its wider context as a European nation and analysing spatial differences within Belgium according to standard demographic indicators (such as average age, proportion of the population 65 and over, dependency ratio, and seniority ratio). In the second section we look at consequences of ageing in terms of health through an indicator that has now become standard, that of healthy life expectancy. We analyse this further by examining some of the diseases associated with individual ageing and the place of the caregiver 
Figure 3 Population of Belgium by age and sex in 1970

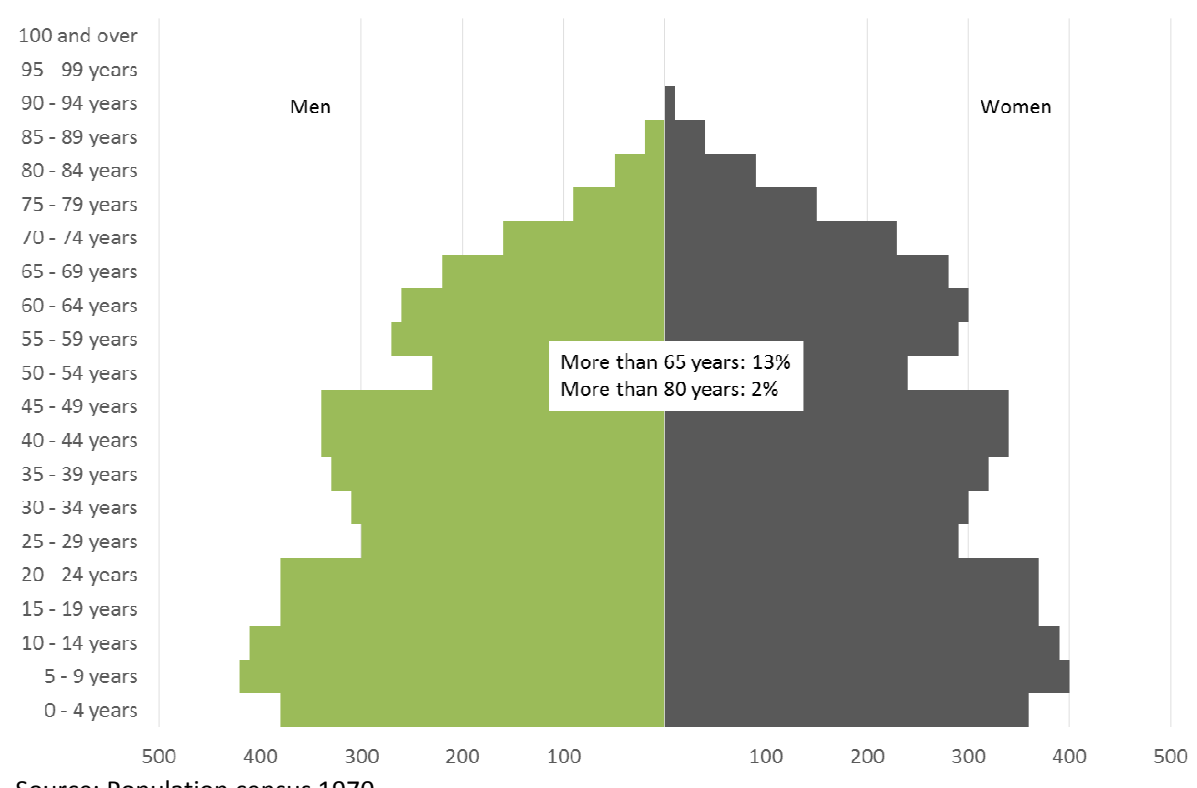

Source: Population census 1970.

\section{Figure 4 Population of Belgium by age and sex in 2015}
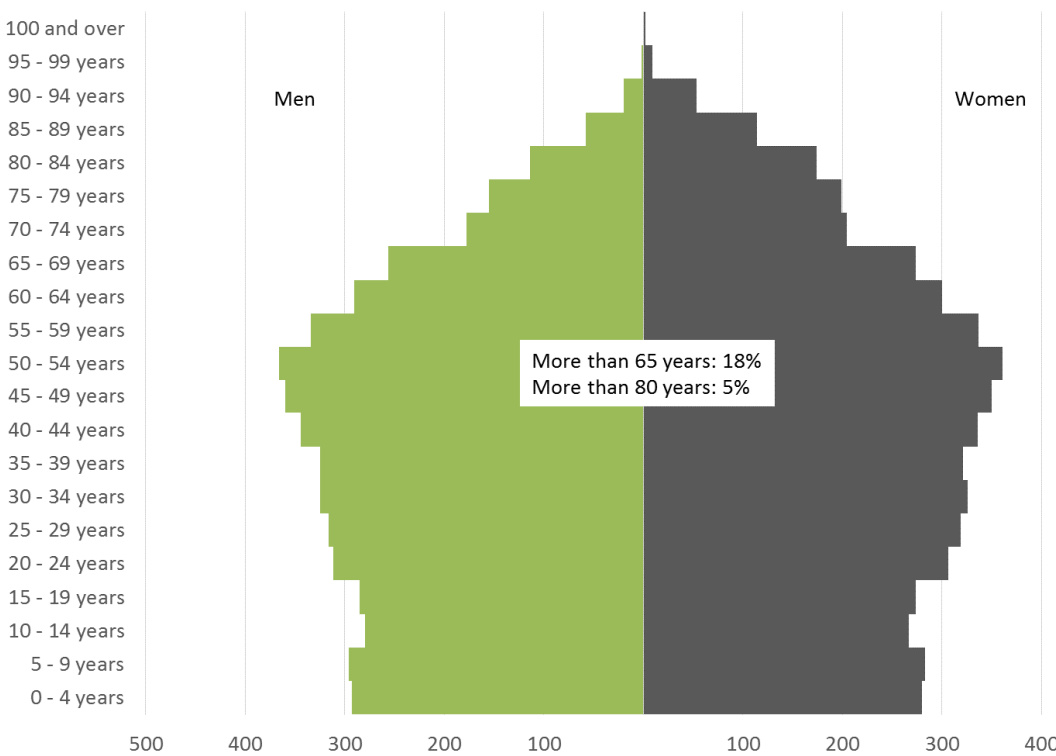

Source: Cytise/National Register, DGSIE. 
within the wider caregiving system for the aged. We devote the third section to the socioeconomic consequences of demographic ageing, in particular issues around retirement, analysing discourses about the three pillars of the retirement pension system, the impact of ageing on the employment rate of populations approaching retirement age, and the demographic argument in regards to increasing of age of retirement (as longevity continues to lengthen). Where possible, we draw comparisons with the situation in other European countries.

\section{Demographic Changes}

About forty years ago the population of Belgium was around 9'656'000. The milestone of 10 million was reached in 1992, and as of January 1 , 2015 , the population was $11^{\prime} 209^{\prime} 044$. This represents an average annual increase of $+0.33 \%$ for the period $1975-2015$, with a slight acceleration toward the end of the period $(0.5 \%$ for $2001-2015)$. Nonetheless, this falls far short of the growth rates previously reached in the nineteenth century (Debuisson et al., 2000). The situation is similar in many other European countries, which, like, Belgium, have experienced increases in their population growth rates since 2000. The exceptions are Luxembourg, whose demographic growth has remained steady, and Germany, affected by demographic decline in its eastern area (Monnier, 2006).

These instances of very low growth are mainly the natural result of a decreasing gap between birth and death rates (Monnier, 2006; Sardon, 2004), and there is a very real possibility that in the relatively near future number of deaths will overtake number of births, thus producing a chronic natural deficit even with increasing longevity (Eggerickx, Tabutin, 2002).

\footnotetext{
How is ageing ideally measured?

In any consideration of the temporal progression of ageing, it is difficult to quickly encapsulate the issues raised in evaluating the notion of ageing. Calot and Sardon (2000) identified the most commonly used measures of ageing (and, indeed, which are used in this article) based on chronological age. In 1989 Bourdelais challenged this focus on chronological age, pointing out that how the notions of ageing and old age are delineated changes over time. The underlying issue, as Feller has shown (2005), is that being 60 years old in the nineteenth century (when the first retirement schemes were being put into place) is quite different from being that age today. Vandresse (2017) suggests adopting the notion of prospective age, that is, the age as of which there would be a certain number of years left to live, estimated according to a population's mortality level. The threshold age would thus vary from one period to another. This definition of ageing is difficult to refute as it takes into account the biological, psychological and social dimensions of ageing. However,
} 
in discussions of processes such as demographic ageing that affect a population's age structure, this notion is less relevant because the objective is to highlight the increased relative weight of those individuals at the top of the pyramid. As Calot and Sardon (2000) noted, in these types of analyses the actual threshold is not what is at stake: what is important is how proportions change over time, allowing for an understanding of evolution in the age structure.

In a graph showing changes to the median age of the populations of several European Union countries (Figure 5), Belgium sits about in the middle, in contrast with Germany, where the increase began later but has been more sustained (Monnier, 2006; Adveev et al., 2011). For 1970, the median age for many of the countries represented on the graph is around 35 (but 28 for the Netherlands and Finland). For 2014, it is around 40 for all the countries (with Germany at a maximum of 45). The graph clearly shows an overall trend, as well as a major convergence (except Germany, where ageing has been more rapid) owing to shrinking disparities between these countries.

FIGURE 5 Median age of the population in various European countries (1960-2016)

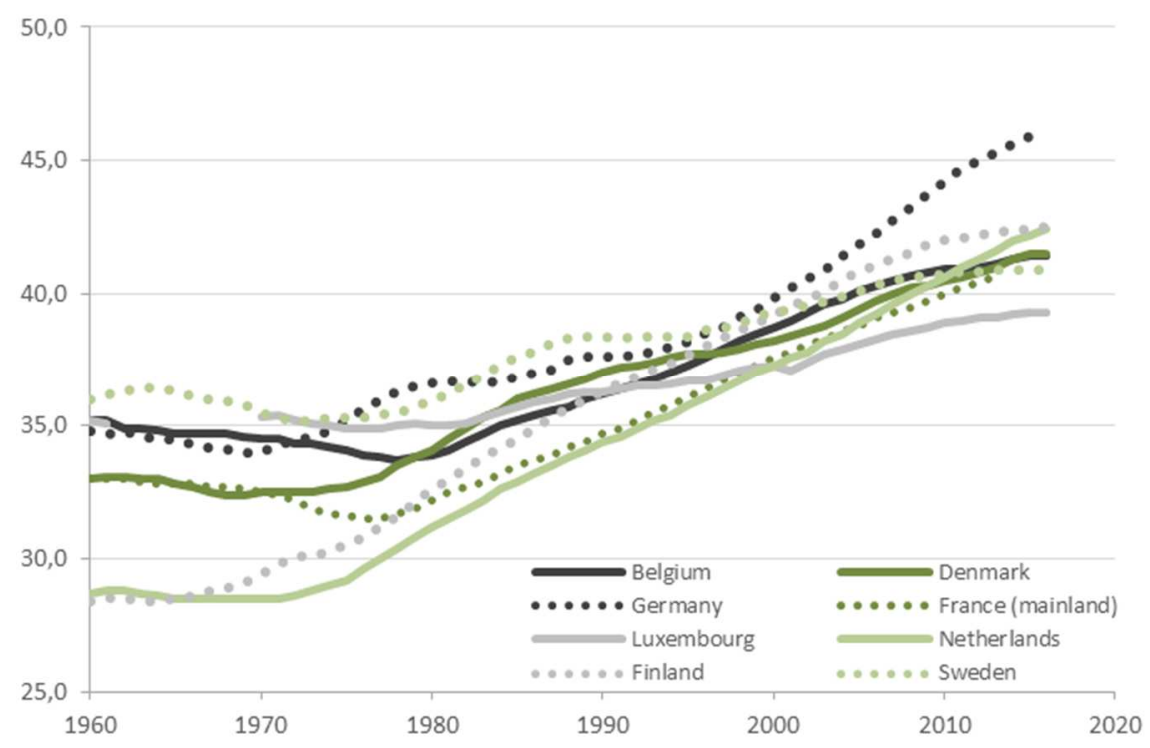

Source: Eurostat, 2015.

Nonetheless, beyond this country-level convergence there are major disparities at the local level. Looking at the situation in Belgium for 2013, the average age at the municipality level fluctuates between 33 and 51 years, 
with a highly unequal spatial distribution. There is an overall divide between Flanders, where the population is older, and Wallonia, where it is younger, and on top of that, within each of these regions the situation is far from homogeneous. In general major cities have younger populations, and there are three areas with excessive ageing (the Belgian coast, the Lesse and Semois/Entre-Sambre-et-Meuse valleys, and a series of municipalities between Antwerp and Genk (Map 2)). These differences point to local contexts that are highly variable and have extremely divergent needs (in particular in terms of home-based care services) (Bourguignon et al., 2017).

\section{MAP 1 Administrative map of Belgium}

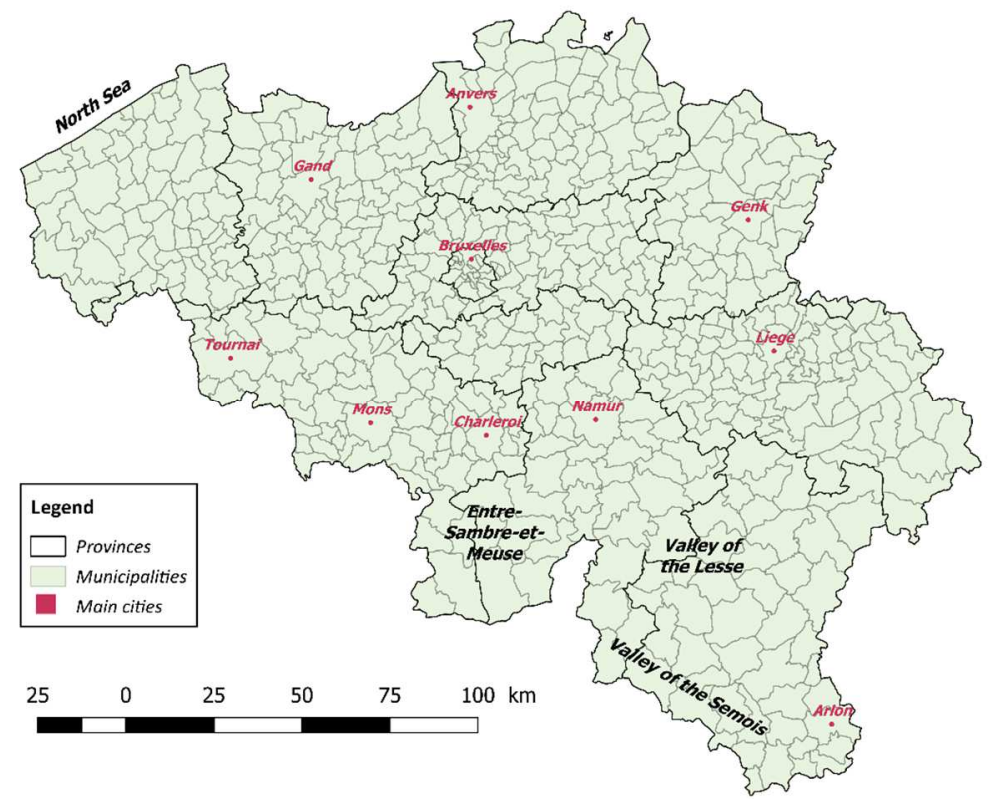

A more revealing way of grasping the phenomenon of ageing is to look at age structure and analyse the relative proportion of older people in the population at large (Figure 6). Since 1960 the proportion of the population that is 65 years of age or older has grown steadily. In 1960, this group represented 12\% of Belgium's population; in 2015 this figure was 18\%, nearly one person in five. Belgium remains close to the European average, near Denmark, France and the Netherlands. This group's relative proportion is expected to continue growing in the coming years, reaching $25 \%$ of the population around 2050, or one person in four (Bureau Fédéral du Plan, Direction générale de la Statistique, 2016). 
MAP 2 Population mean age of the Belgian municipalities (2015)

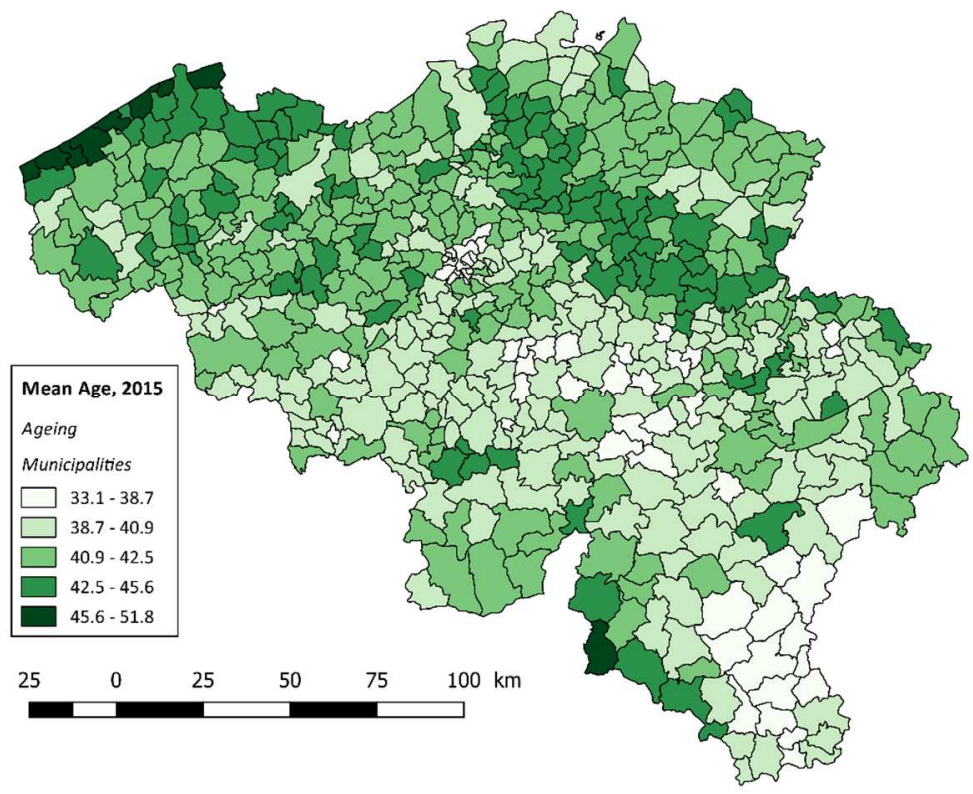

Source: National Register.

FIGURE 6 Percentage of population aged 65 and over in various European countries (1960-2016)

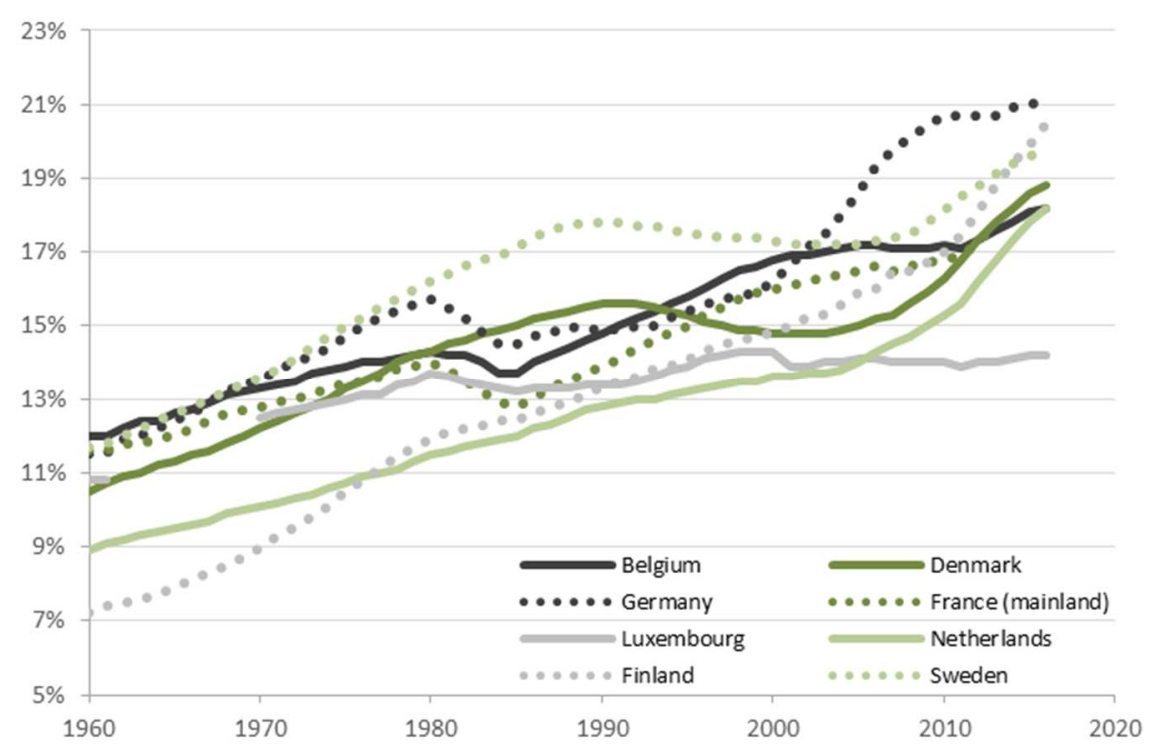

Source: Eurostat. 
If the relative weight of those aged 65 years or more has markedly risen, an ageing process within this group has also taken place. Between 1970 and 2015, the age groups in Belgium that experienced the greatest growth are the nonagenarians and the centenarians, whose numbers increased fivefold and eightfold, respectively - what has been termed «ageing within ageing» (Eggerickx, Tabutin, 2002). This is all the more so because in the meantime the 65-79-year-old group has hardly changed (Figure 7). This trend is expected to continue in the coming years (Bureau Fédéral du Plan, Direction générale de la Statistique, 2016) with the numbers of centenarians continuing to grow. These developments could have implications for social security programmes given that the oldest members of society are also the ones with the greatest need for health-care services (Henrard, 1997).

FIGURE 7 Relative trend $(1970=100)$ of age groups

65 and over in Belgium, 1970-2015

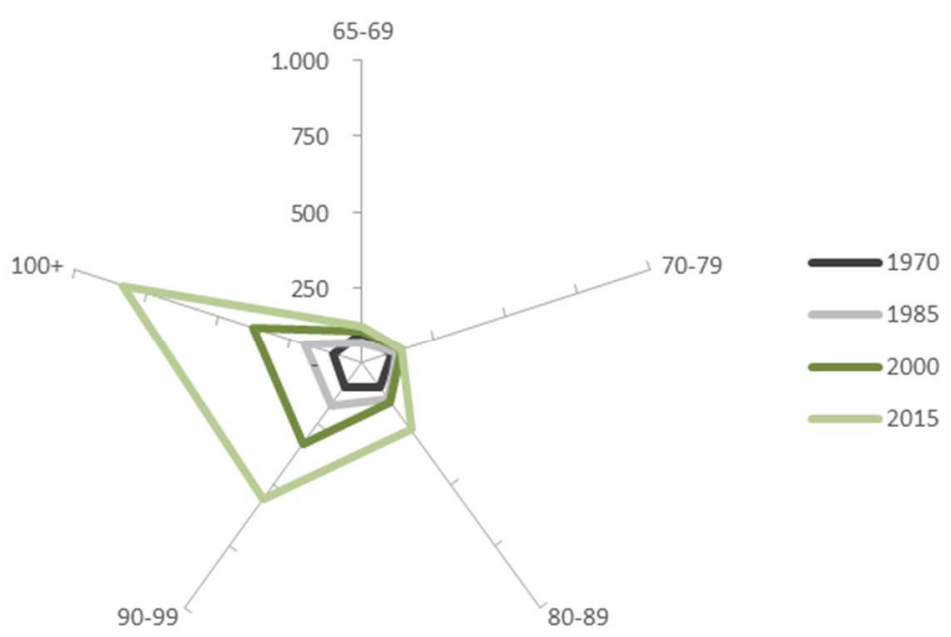

Source: National Register.

At the regional scale there has been a reversal. Up until 1970 the proportion of those aged 65 years or more was higher in Wallonia than in Flanders (due to the demographic transition getting under way earlier in Wallonia (Map 3-4). In 2015, there is still a clear North-South division, except that the proportions have been reversed: there is now excessive ageing in Flanders in comparison to Wallonia and the Brussels-Capital Region, both with younger populations. However, the two regions did have one 
characteristic in common: in 1970 their large cities (such as Antwerp, Ghent, Brussels and Liège) all featured excessive ageing, while in 2015 these same cities were now demographically younger than the average. This recent trend in urban under-ageing is in large part due to international immigration, which principally involves working-age people who migrate for economic reasons and affects the age structure of the areas that receive them (Rérat, 2016). The relatively young character of these urban areas is rendered especially obvious by their contrast with nearby peripheral areas, marked by intensified ageing.

Beyond these general observations, the situation is variable within each region. Flanders is divided into three zones with a clear east-west cleavage: the districts of East and West Flanders are older and that of Limburg is younger, and in between is a typical intermediate central axis. This spatial distribution within Flanders has historical roots, especially in terms of fertility, Limburg having been the most fertile part of the country until the 1970s. On the Walloon side, excessive ageing is especially noticeable in the South, especially in districts along the border with France, which are popular among migrants aged 50 years or more (Sanderson, 2013). It is clear that these areas do not pose the same needs in terms of services and care for the aged as do the municipalities in central Wallonia where the population is younger (Bourguignon et al., 2015).

Spatial distribution maps at the local level in terms of the proportion of people aged 80 years or more show similar trends in 1970 and 2015 (Map 5-6).

The ageing phenomenon is not only seen for those aged 65 years or more: younger populations are also affected, in particular those of working age. ${ }^{3}$ Changes to this group over the past few decades have been less pronounced than to those at the top and bottom of the age structure. For the past 150 years, those aged $20-59$ years have represented about $50 \%$ of the population. Yet looking more closely at this apparently stable age group reveals that it has been through profound internal change (Figure 8). Until 1970-1981, those aged 20-39 and 40-59 followed the same overall trajectory but with a shift of about 20 years, which brought them to converge soon after the Second World War. In 1947, those in the 20-39year-old cohort were born between 1907 and 1927, a period when birth control was becoming widespread throughout the country; that same year, those born in 1887-1907, when women were more fertile, were now 40-59 years old.

3. This group is usually defined as those between 20 and 64 years of age even though most of them stop working before reaching 60 (Sanderson, 2014). 
MAPS 3-4 Percentage of population aged 65 and over in Belgium (1970 and 2015)
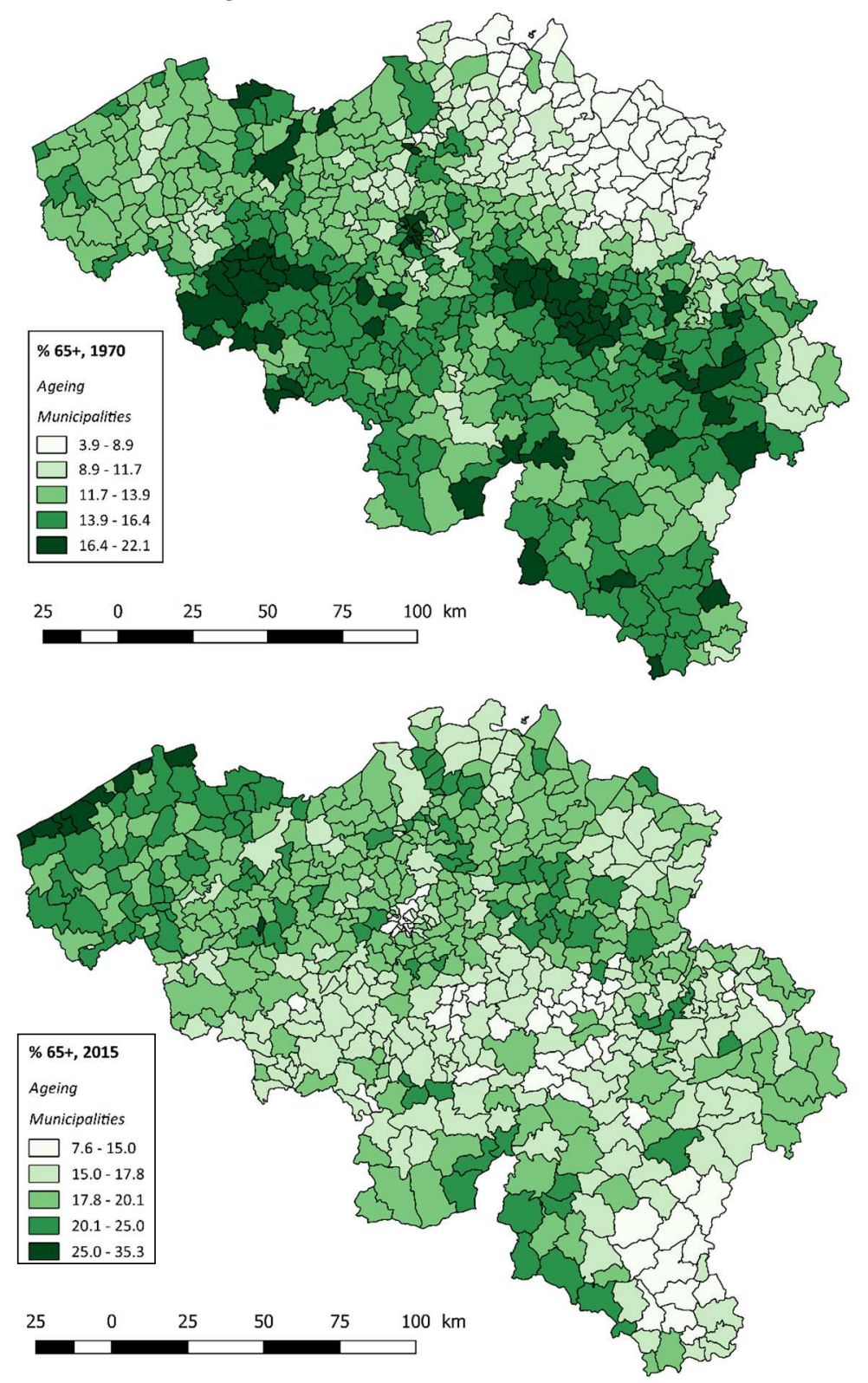

Source: National Register. 
MAPS 5-6 Percentage of population aged 80 and over in Belgium (1970 and 2015)
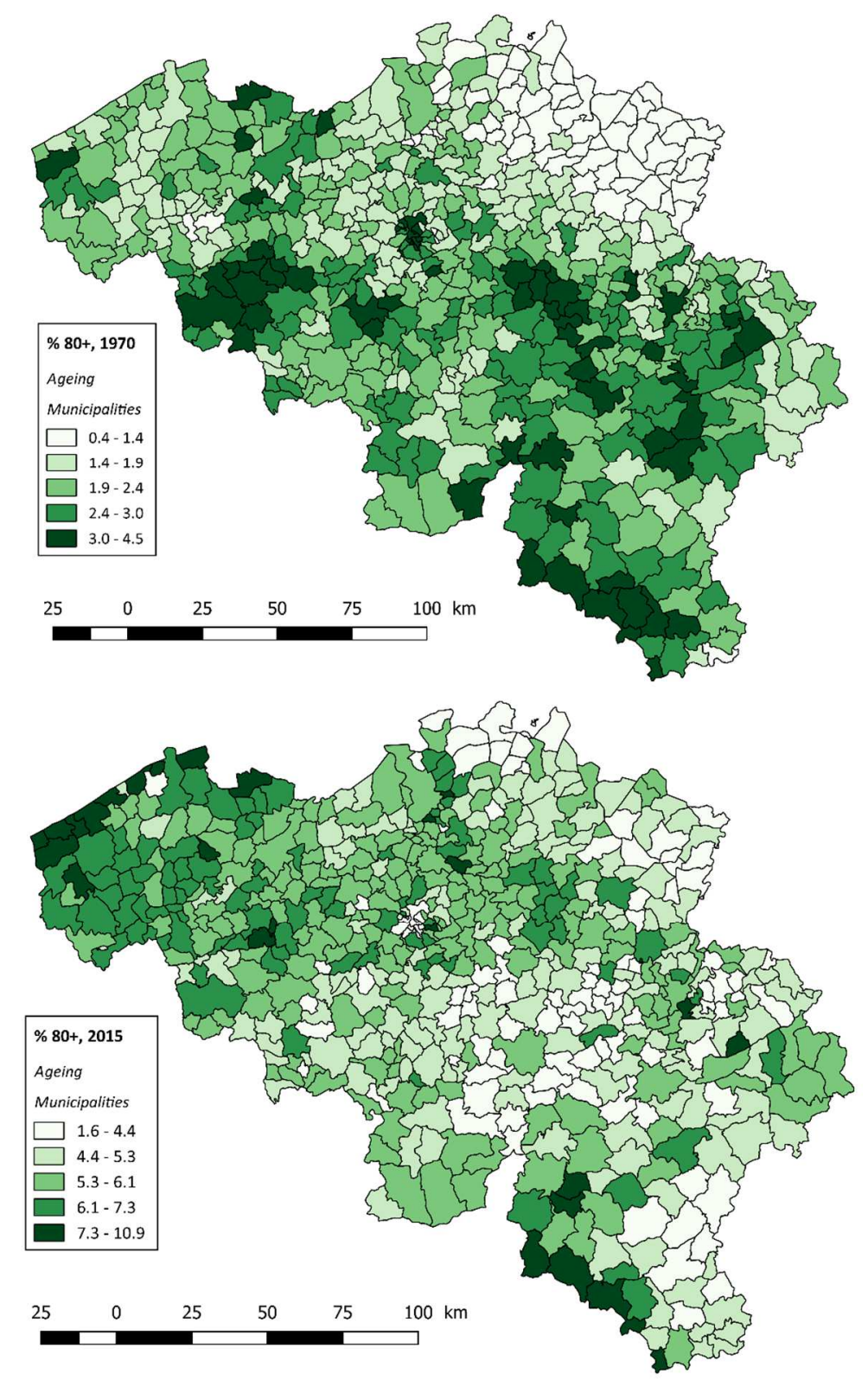

Source: National Register. 
FigURE 8 Evolution of labour force by age-groups and ageing of persons of working ages in Belgium, 1846-2015

Working ages

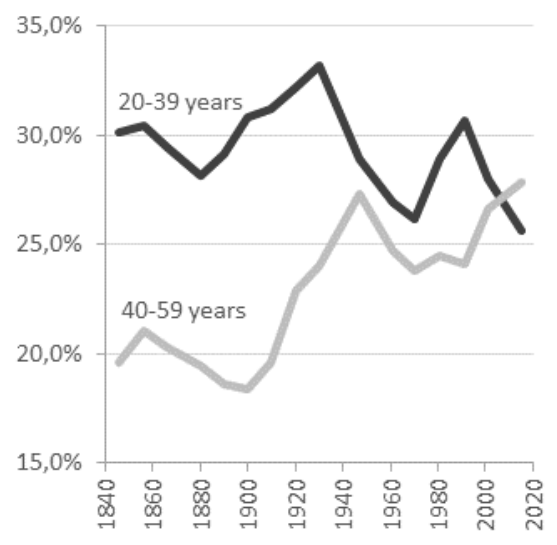

Ageing of persons of working ages (40-59/20-39)

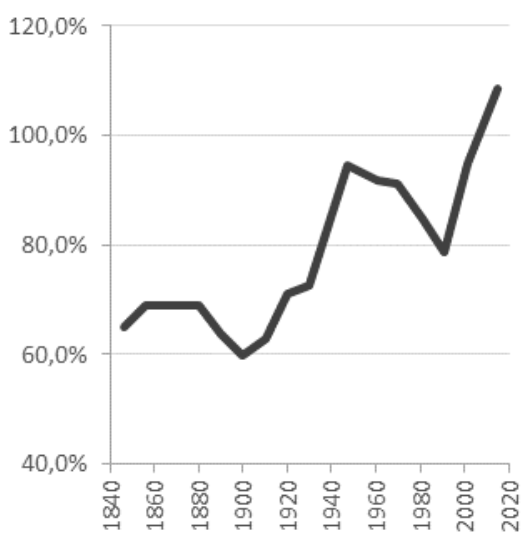

Source: National Register.

FIGURE 9 Ageing of working age population (40-59/20-39)

in various European countries, January 1st, 2015

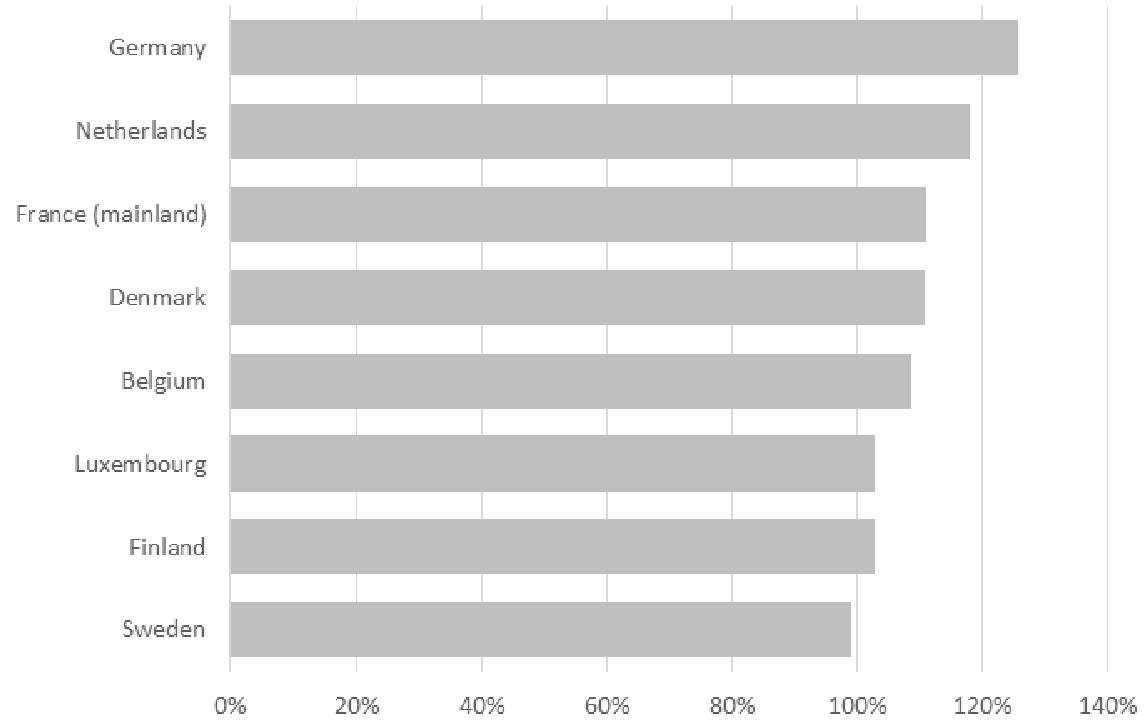

Source: Eurostat.

As of 1981 the two curves begin to diverge; the relative proportion of the 20-39-year-old group decreases as it comes to incorporate the «baby 
busters», while the proportion of the population that is 40-59 years old increases quickly as the «baby boomers» enter this category. These contrasting trends result in a quickly ageing working-age population (Figure 8). The two curves cross in 2005, after which the percentage of 40-59year-olds is higher than that of 20-39-year-olds (whereby the ageing ratio for the working-age population is greater than 100). This situation has only intensified since then, with extremely rapid growth among 40-59year-olds and a shrinking of the population 20-39 years, leading to a marked ageing of the wider working-age population.

This trend has also been a feature of other European countries - France, Germany, the Netherlands, Denmark, Finland and Sweden - albeit in varying proportions. The trend in Belgium is at the intermediary stage, as it is in France and Denmark, whereas in Finland, Sweden and Luxembourg, it is just getting started. In Germany and the Netherlands, where workingage populations have aged the most, the reversal has been particularly pronounced (Figure 9).

The consequences of demographic ageing are not purely economic; they are also social, especially in terms of isolation among older people, and even more so because when they become dependent, the primary caregiver is usually the spouse (Gaymu, 2009). The question of intergenerational relations can be broached by looking at household composition for older people (Table 1). Up until 79 years old it is common for both men and women to be living as a couple. Starting at 80 years old this remains common for men but less so for women, $48 \%$ of who now live alone. The problem of isolation is already significant among 65-79-year-olds, with $31 \%$ of women and $17 \%$ of men living alone. The proportion of those living in collective households increases with age, particularly among women.

TABLE 1 Distribution of population aged 65 and over according to household type (Belgium, 2015)

\begin{tabular}{|l|c|c|c|c|c|c|}
\hline & $\begin{array}{c}\text { Couple without } \\
\text { children }\end{array}$ & $\begin{array}{c}\text { Couple with } \\
\text { children }\end{array}$ & $\begin{array}{c}\text { Collective } \\
\text { households }\end{array}$ & Isolated & $\begin{array}{c}\text { Single-parent } \\
\text { households }\end{array}$ & Others \\
\hline Men 65-79 years & $66 \%$ & $9 \%$ & $1 \%$ & $17 \%$ & $2 \%$ & $6 \%$ \\
\hline $\begin{array}{c}\text { Women } 65-79 \\
\text { years }\end{array}$ & $52 \%$ & $5 \%$ & $2 \%$ & $31 \%$ & $4 \%$ & $6 \%$ \\
\hline $\begin{array}{c}\text { Men 80 years and } \\
\text { over }\end{array}$ & $55 \%$ & $5 \%$ & $7 \%$ & $25 \%$ & $2 \%$ & $5 \%$ \\
\hline $\begin{array}{c}\text { Women 80 years } \\
\text { and over }\end{array}$ & $21 \%$ & $2 \%$ & $17 \%$ & $48 \%$ & $6 \%$ & $7 \%$ \\
\hline
\end{tabular}

Source: National Register. 
FIgURE 10 Trends in the distribution of the population aged 65 and over according to household type (1991=base 100; in brackets percentage of each type of household in 2015)

Men 65-79 years old

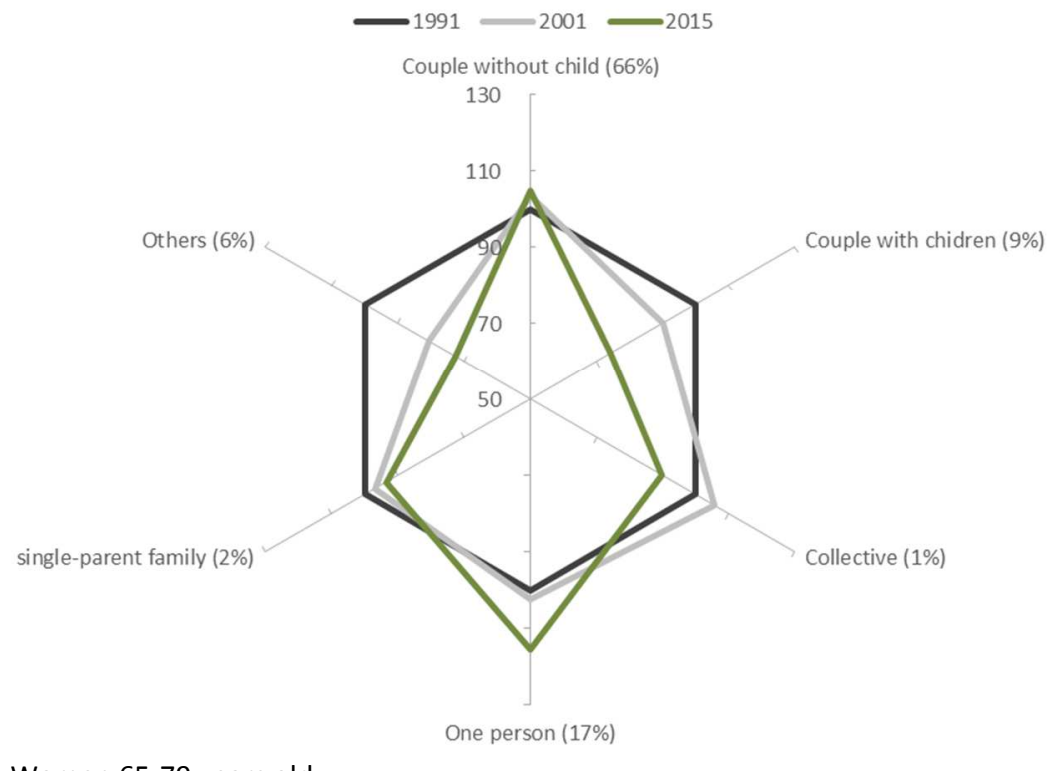

Women 65-79 years old

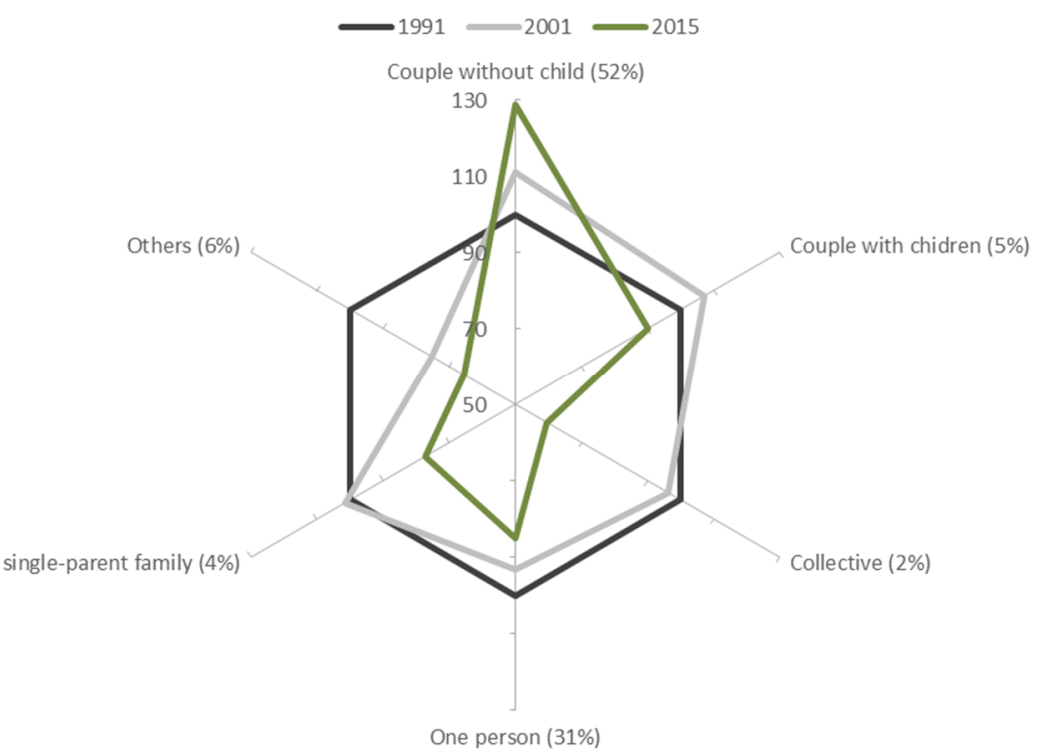


Men aged 80 and over
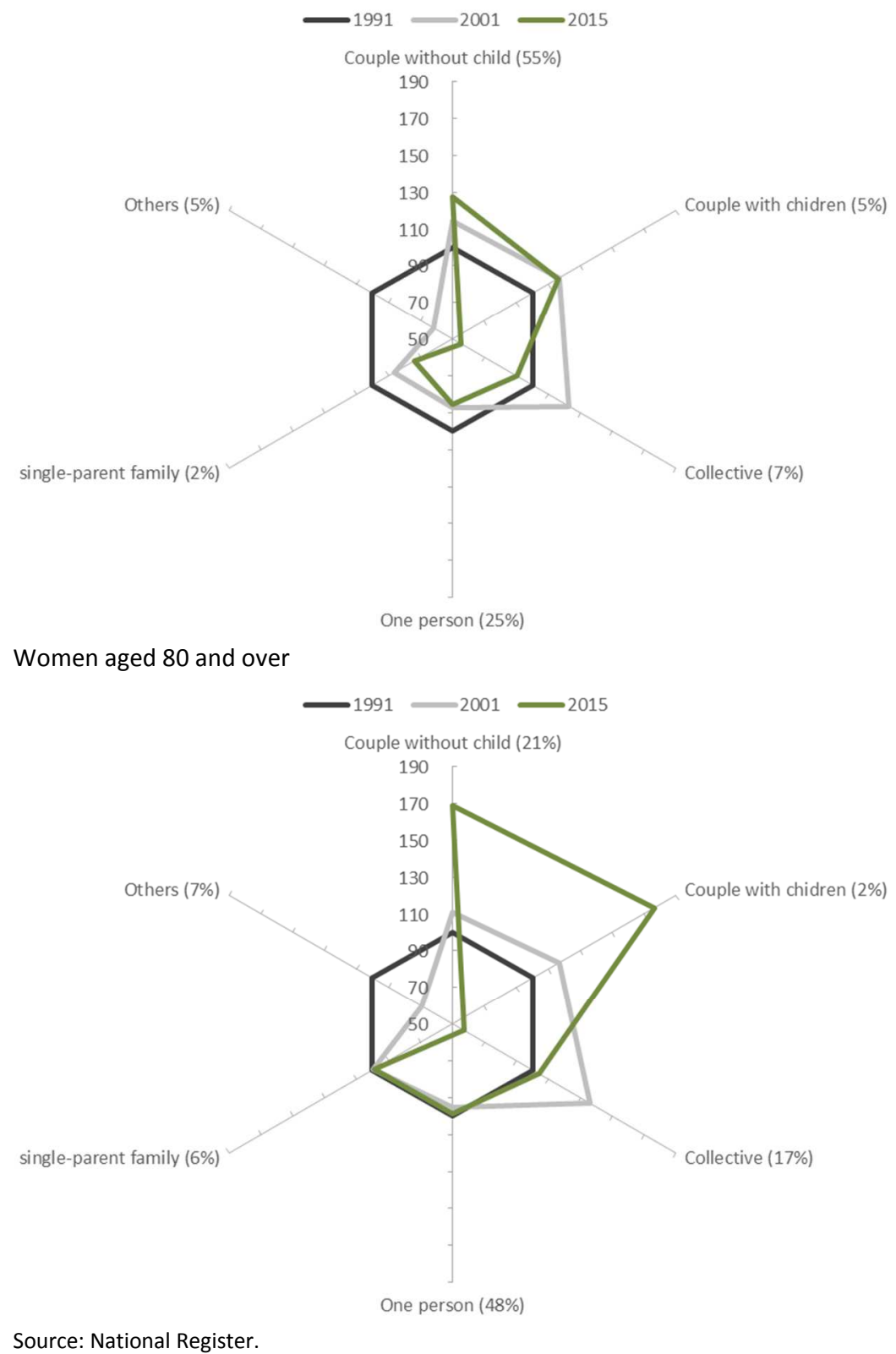

The changes have been striking (Figure 10). Between 1991 and 2001, each of the categories (except women 65-79 years old) has seen a clear increase in the numbers of those living in collective households (even 
though their proportion remains low, apart from women 80 years old or more).

Recent trends indicate an increase in the proportion of people living with a spouse or otherwise cohabitating at all ages, but especially among women. This is in part related to an increasing life expectancy whereby both spouses are surviving longer and widowhood is pushed back to very old age. Nonetheless, there is no reason to believe that this situation will persist in future generations: indeed, those who reached old age more recently were born after the start of the second demographic transition. Yet this transition could at least have a partial effect with the increase in oneperson households (Lesthaeghe, Surkyn, 2004; Adveev et al., 2011).

\section{Ageing and Loss of Vitality: Parallel Processes?}

\section{A close relationship between age and health}

Since 1841 life expectancy has gone up in Belgium at an average rate of three months per year. In 2014, in comparison with the other 27 European Union countries, Belgium was positioned somewhere in the middle in terms of life expectancy at birth (81.4 years for both sexes combined). Countries with even higher life expectancy in Western Europe include Luxembourg (82.3 years) and France (82.8 years), and in Southern Europe Italy (83.2 years) and Spain (83.3 years) (Figure 11). However, for a number of countries, especially in Eastern Europe, there is significant room for improvement, with life expectancy at birth at around 75 years, such as Bulgaria (74.5 years), Latvia (74.5 years), Lithuania (74.7 years), Romania (75 years) and Hungary (76 years) (Adveev et al., 2011).

Differences - in some cases significant - persist between men and women in terms of life expectancy, with women having a longer overall average lifespan than men (Lefèbvre et al., 2014; Vallin, 2002). In 2014 in Belgium the gap was just over 5 years, but for some countries, it can be even wider. In 2014 this was the case for most of the EU-28 countries with lower life expectancies, including Poland (a gap of 8 years between sexes), Estonia (9.5 years), Latvia (10.3 years) and Lithuania (10.9 years) ${ }^{4}$.

4. From data published by Eurostat for 2014 . 
FIGURE 11 Life Expectancy at birth by sex in various European countries, 2014

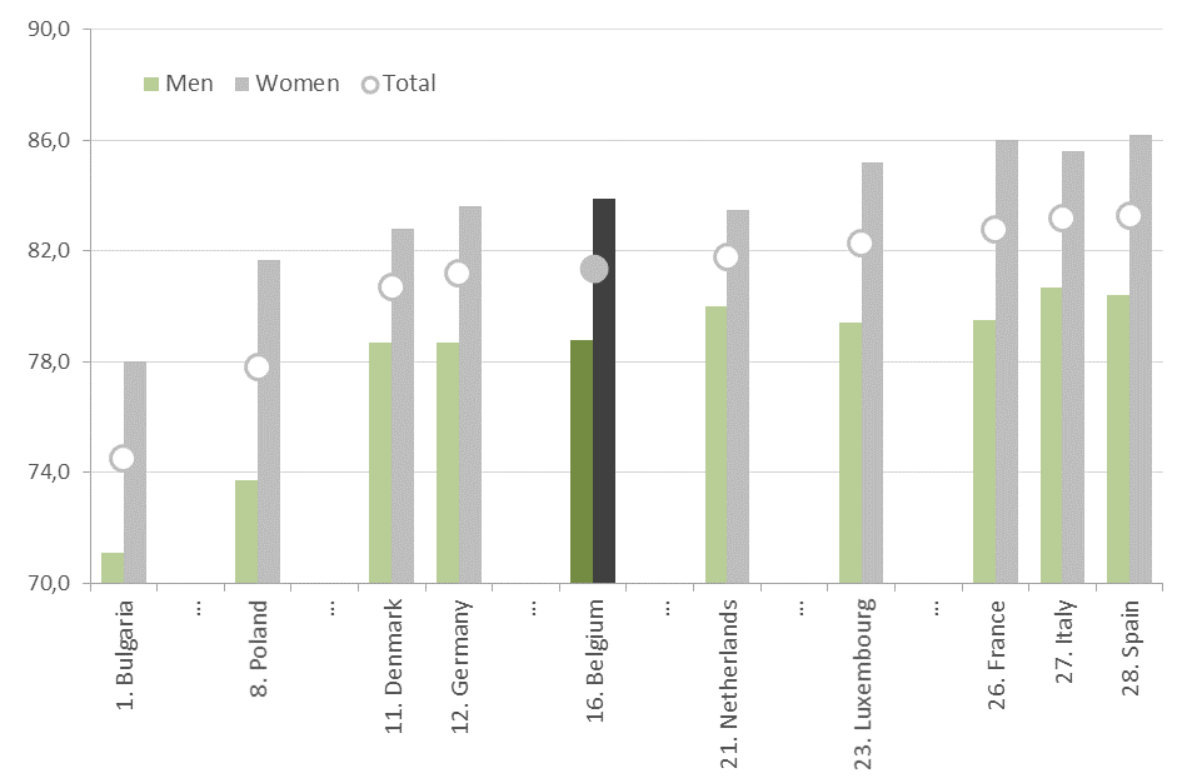

Source: Eurostat.

Nonetheless, this sex difference is nuanced by the fact that by virtue of living longer, women also spend a greater span of their life in poor health (Figure 12), a factor that generally translates into increased isolation (taking into account the difference in mortality between men and women). If we focus only on healthy life expectancy, ${ }^{5}$ male/female differences shrink and may even disappear or become negative. ${ }^{6}$ In several Eastern European countries where the difference between male and female life expectancy approaches 10 years, women's advantage in terms of total lifespan is mainly explained as a longer average unhealthy

5. Data on healthy life expectancy was drawn from the Eurostat database. According to Eurostat, this indicator «measures the number of remaining years that a person of specific age is expected to live without any severe or moderate health problems» (Eurostat, Reference Metadata). Eurostat goes on to explain that the notion of «health problem» is «reflecting a disability dimension and is based on a self-perceived question which aims to measure the extent of any limitations, for at least six months, because of a health problem that may have affected respondents as regards activities they usually do» (Eurostat, Reference Metadata). Thus the indicator of healthy life expectancy includes two elements: that of mortality and that of health (the latter based on a specific question posed in the EU-SILC survey). See http://ec.europa.eu/ eurostat/cache/metadata/en/hlth_hlye_esms.htm.

6. In this case this means that men have a longer average healthy lifespan than that women. 
lifespan. The gap between healthy and unhealthy life expectancy accounts for around $60 \%$ of the total gap in life expectancy at birth between men and women. In countries such as France, Germany, Spain and Denmark, these sex differences are reduced to nearly zero if healthy life expectancy is taken into account, highlighting the relevance of the distinction between «quality of life» and «quantity of life». Even more surprising is that in other countries, including Belgium but also Italy and especially Luxembourg and the Netherlands, women show no advantage at all in terms of healthy life expectancy; ${ }^{7}$ in fact, in these countries it is actually men who are at an advantage because in 2014 their healthy life expectancy was longer than that of women. Although these trends do not apply to the entire period under study, they nonetheless show that lifespan, longer on average for women, is an indicator of «quantity of life», of which the relationship with individual health and well-being is far from simple.

The subjective health indicator confirms these observed discrepancies between men and women. These are in part due to an effect of selection of populations in good health across all ages (a corollary of male excess mortality is an increased selection of individuals in better health). Two significant points can be derived from Figure 13. On one hand, the association with good health and age is negative: the proportion of individuals in good health diminishes with increasing age. On the other hand, the gap between men and women widens with age, with the exception of those 55 to 64 years old, the only group with an equal proportion of men and women claiming good health. At older ages, the opposite occurs: when differences in life expectancy between men and women, and the selection effect this implies, are taken into account, men that live to a very old age claim better overall health than women the same age.

\footnotetext{
7. According to Meslé (2004), differences in the gaps between male and female life expectancy are due at least in part to disparities between sexes in terms of certain disease pathologies and their relative weight in patterns of national mortality.
} 
FIGURE 12 Gap between life expectancies in good/bad health of men and women in various European countries, 2014

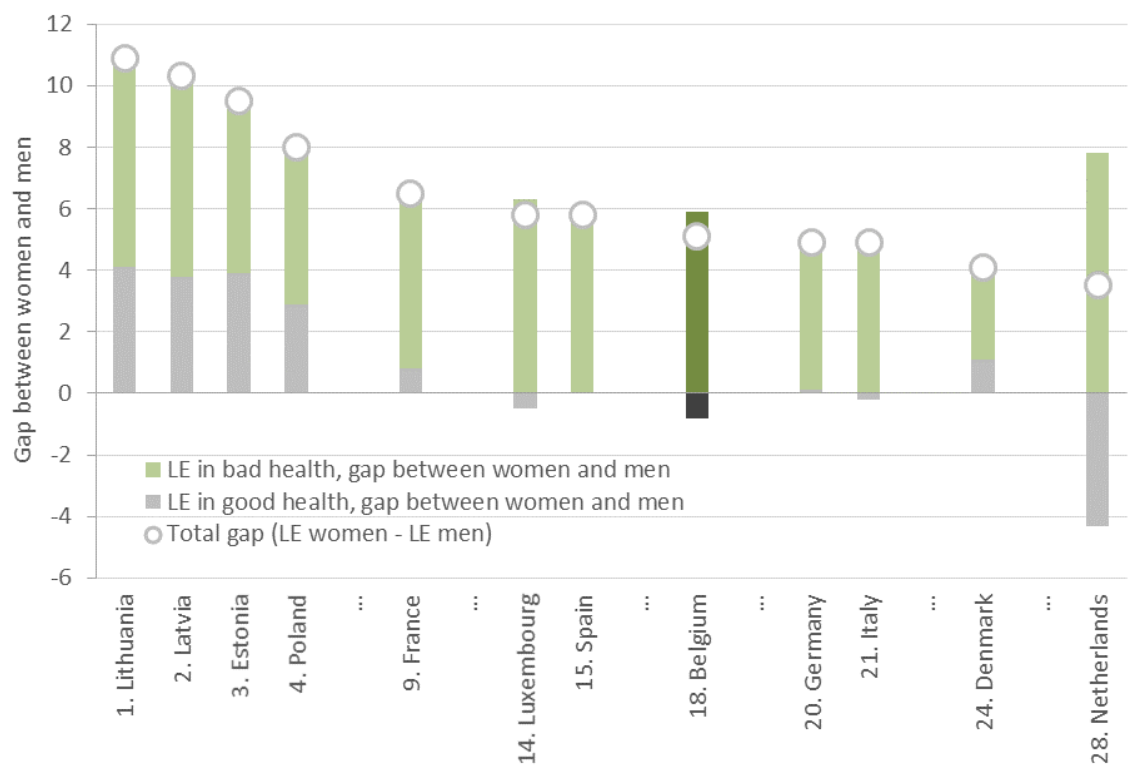

Source: Eurostat; Authors' calculations.

FIGURE 13 Percentage of population reporting (very) good health (subjective health indicator), Belgium, 2013

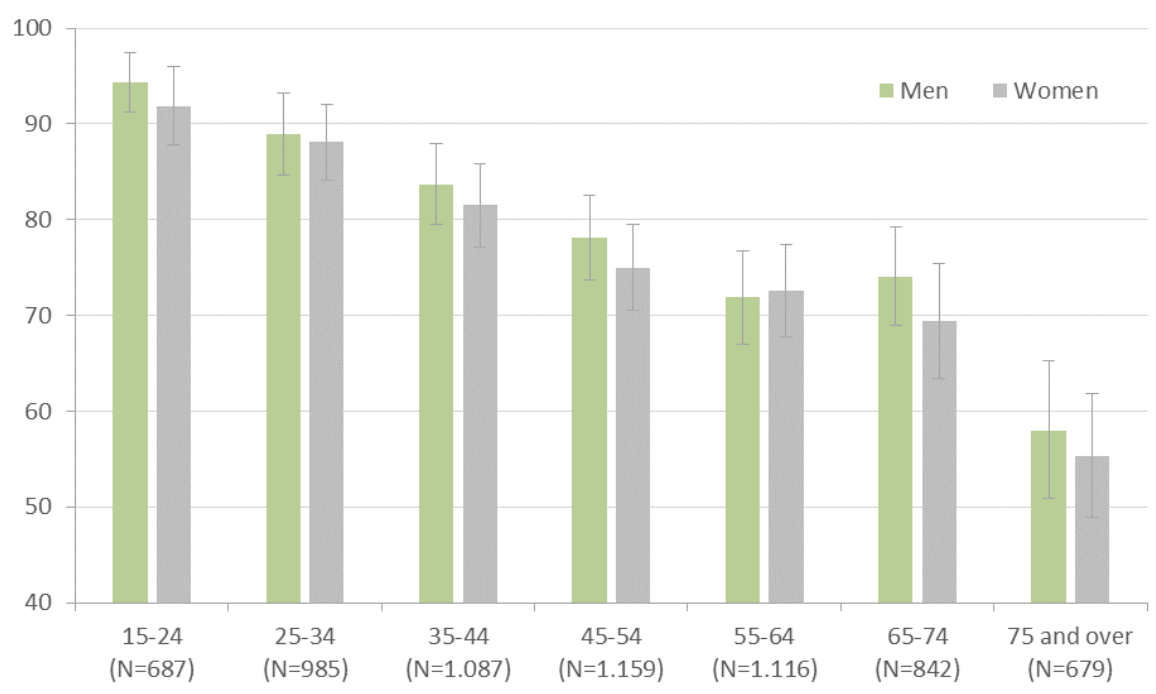

Source: Health Interview Survey, Belgium. 
Improvements in quality of life and in medicine have led to an increase in life expectancy since around the second half of the nineteenth century. This increase, however, has come with a higher incidence of chronic or long-term diseases and handicaps, especially at the oldest ages (Bopp, 2013). These trends are confirmed by the Belgian data from the 2013 Health Interview Survey, with long-term ailments more and more frequent, especially among the oldest people (Figure 14). One person in three aged 75 years or more suffers from multimorbidity (Figure 15), that is, the co-occurrence of at least two chronic illnesses (Bopp, 2013; Bopp, Holzer, 2012). These incidences of multimorbidity necessitate changes to the health-care system in recognition of the slow development of these illnesses and their long-term nature.

\section{FIGURE 14 Distribution of population according to the presence of one or more important ${ }^{8}$ chronic diseases detected during the previous year, Belgium, 2013}

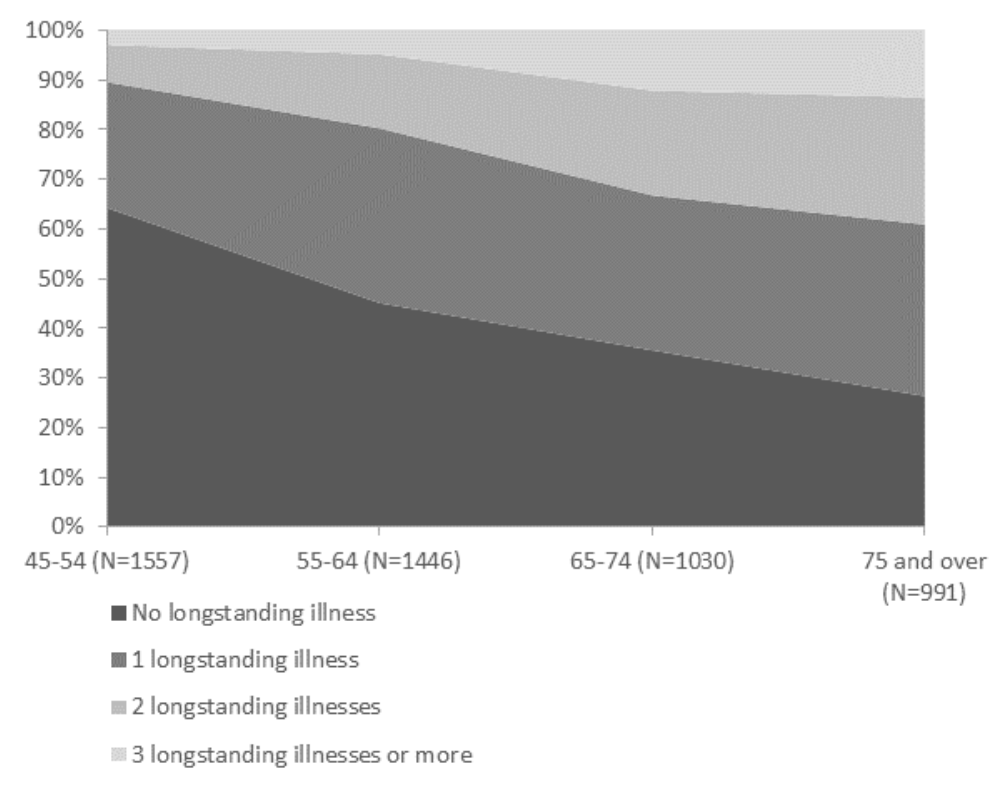

Source: Health Interview Survey, Belgium

8. Chronic diseases here include chronic respiratory diseases, serious cardiac diseases, diabetes, arthritis/osteoarthritis, hypertension and cancer (HIS, 2013). 
FIGURE 15 Distribution of the population suffering from one or more chronic diseases, long-term conditions or handicaps according to the restrictions in the daily activities, Belgium, 2013

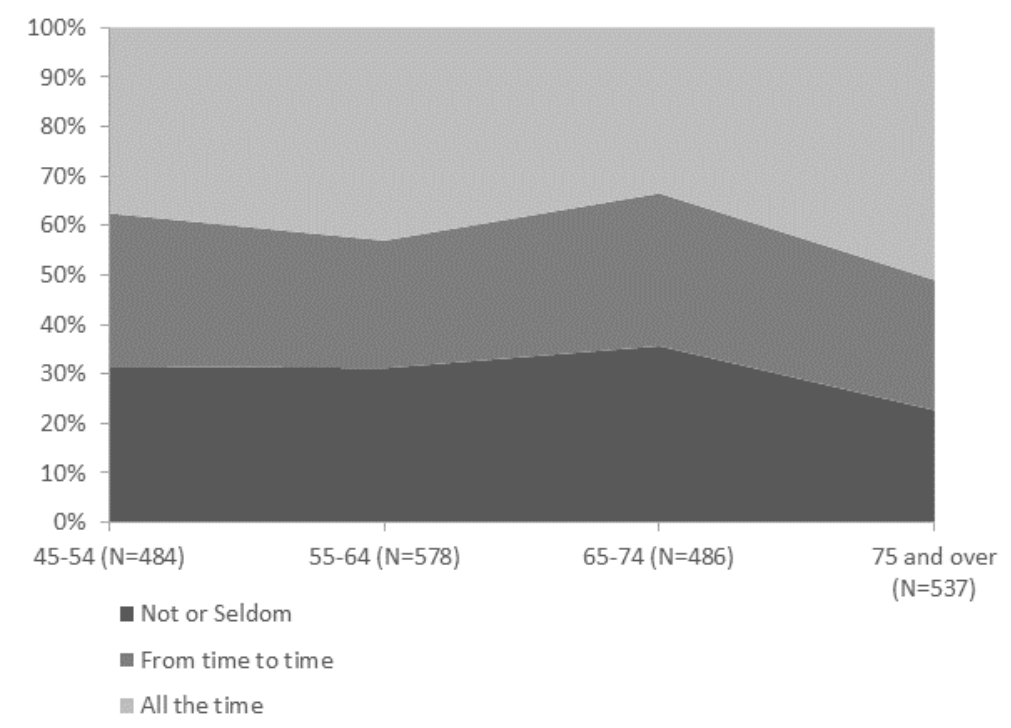

Source: Health Interview Survey, Belgium

\section{Physical and Psychological Problems: A «Heavy Burden»}

In Belgium, men and women suffer from the same chronic diseases overall, albeit with minor differences in order. The most common disease among women is osteoarthritis, with a 50\% prevalence rate; for men this rate is only $28 \%$. For men the most common disease is hypertension (which increases the risk of cardiovascular disease), of which the prevalence rate for men and women is the same. In terms of chronic diseases, the most common are musculoskeletal illnesses, with high prevalence rates for both men and women.

This ranking of the most common chronic diseases does not include dementia, depression and other psychological ailments even though their prevalence increases with age. Dementias are among the most commonly occurring ailments that have repercussions for the aged in terms of daily life. Dementia as a category includes a wide variety of specific diseases, including Alzheimer's which accounts for about $60 \%$ of cases of dementia (Ivanoiu, 2000 cited by Charlot, Guffens, 2007). 
Figure 16 Most common chronic diseases in the population aged 65 and over, Belgium, 2013

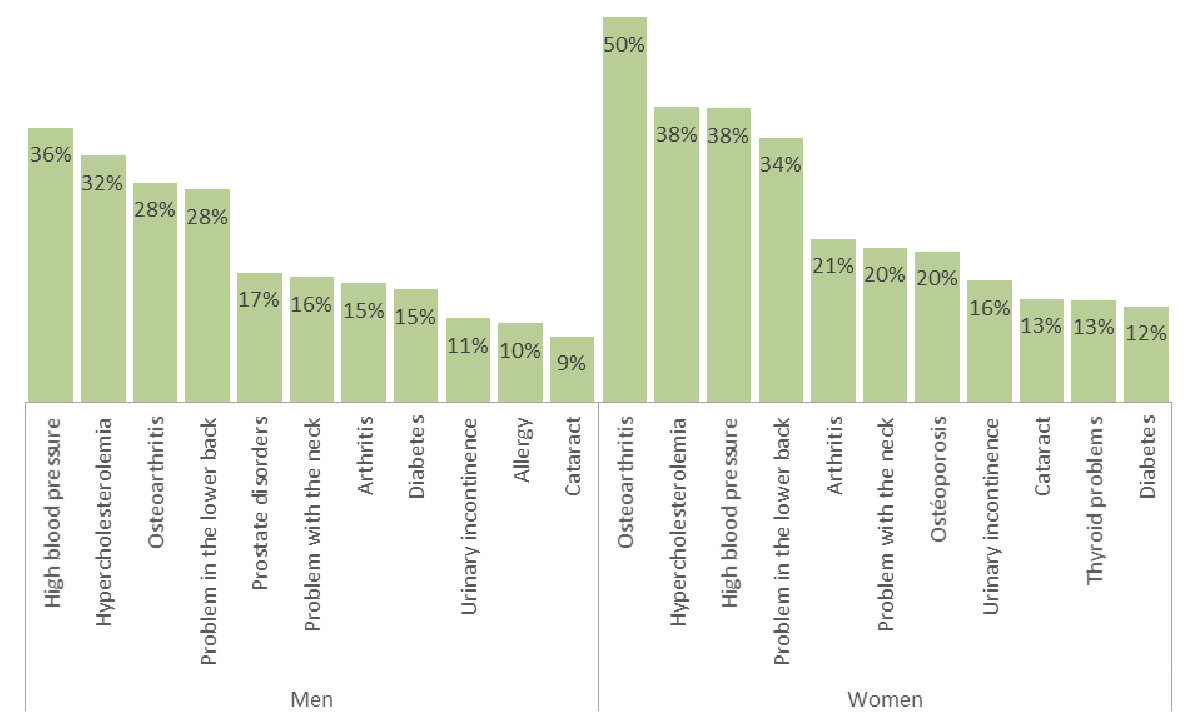

Source: Belgian HIS in Van der Heyden and Charafeddine, 2014, p. 13.

According to the Tenth Revision of the International Statistical Classification of Diseases and Related Health Problems,

\begin{abstract}
« Dementia (...) is a syndrome due to disease of the brain, usually of a chronic or progressive nature, in which there is disturbance of multiple higher cortical functions, including memory, thinking, orientation, comprehension, calculation, learning capacity, language, and judgement. Consciousness is not clouded. The impairments of cognitive function are commonly accompanied, and occasionally preceded, by deterioration in emotional control, social behaviour, or motivation. This syndrome occurs in Alzheimer disease, in cerebrovascular disease, and in other conditions primarily or secondarily affecting the brain» (World Health Organization, ICD-10, 2016 version).
\end{abstract}

Although this is a precise definition, it is difficult to ascertain the prevalence of dementias with any exactitude. Significant differences exist between data sources. According to Alzheimer Europe's published figures for 2012 , only a very small proportion of the EU-28 population $-1.55 \%-$ has dementia, with Belgium near the top of the ranking at $1.77 \%$, just below Italy (2.09\%), Germany (1.92\%), France (1.85\%) and Sweden (1.82\%) (Alzheimer Europe, 2013). Based on these figures the Belgian population thus has at least 190'000 people suffering from dementia (Alzheimer Europe, 2013). Although these figures do not reveal age differences, the frequency and severity of dementia does increase with age. Vandeurzen's figures (2010, cited by Alzheimer Europe, 2013, p. 16) put 
at around $10 \%$ the proportion of the Flemish population aged over 65 years, around $20 \%$ over 80 years and around $40 \%$ over 90 years. Extrapolating for all of Belgium, a 10\% prevalence for those over 65 years old would mean around $200^{\prime} 000$ people in 2015 , rising to around $310^{\prime} 000$ by 2050 if this prevalence is maintained. ${ }^{9}$ Yet these estimates must be treated with caution because other factors influence the incidence and prevalence of dementia as much as age does, such as sex (dementia is more common among women), family history and the presence of hypertension (Ankri, 2009).

The various forms of dementia often translate into a progressive loss of independence as well as a string of social, family and economic problems (Charlot, Guffens, 2007). Dementia can bring about a number of behavioural challenges which can affect and complicate the life of the dementia sufferer as well as that of their caregiver(s) (Charlot, Guffens, 2007, p. 12). In the beginning home care services, professional involvement and close family support may be enough, but inevitably a transfer to a new, specially adapted residential situation is soon required (Charlot, Guffens, 2007, p. 12).

The "Burden»" ${ }^{10}$ of Family Caregivers: The Recognition of this Status in Belgium as a First Step Towards its Incorporation into Policy

Despite the involvement of a wide range of professionals now working to improve quality of life for the aged, the family caregiver remains central to their care (Gimbert, Malochet, 2012), even where professional help is readily available. Belgian data from the Health Interview Survey show that $85 \%$ of individuals living with some kind of limitation to their basic activities of daily living have a caregiver, with 39\% having a professional caregiver, 38\% having family caregivers and 24\% having both (Masuy, 2010). However, when it comes to the instrumental activities of daily living, the proportion with both types of caregivers rises to $63 \%$ versus only $17 \%$ with professional help only and $17 \%$ with informal help only (Masuy, 2010). Other studies show that for all of Europe, including countries

9. These estimates are based on population projections developed by the Federal Planning Bureau (Bureau Fédéral du Plan, Direction générale de la statistique, 2016). Figures on the prevalence of dementia are drawn from those published on the Alzheimer Europe (2013).

10. The term «burden» should be approached with caution as it connotes the idea that the aged are a heavy weight on society. We do not wish to perpetuate this view. We use this term as it is used in the literature on caregivers to highlight the load often borne by caregivers, especially informal caregivers (Boutoleau-Bretonnière, Vercelletto, 2009). 
with efficient health services for the aged, «nearly $80 \%$ of care hours devoted to dependent elderly people are provided by family members» 11 (Huber et al., 2009 cited by Gimbert et al., 2012, p. 131).

The crucial role played by informal caregivers in home care and in healthcare systems for older people is largely because of the company they provide as well as assistance with daily activities. Some older people need long-term care and thus require not just therapeutic care but permanent or near-permanent support. The close relationship that family caregivers have with older people means that the role they play in care regimes is vital. Professional services, on the other hand, are often rigidly scheduled and focused on specific issues, as well as taking a therapeutic approach, most often monopathological, that does not take into account the contributions of their professional caregivers to their patients.

The caregiving responsibilities involved in having an older person in the family are not evenly distributed among family members. The literature shows that most family caregivers are immediate family members, primarily spouses, children and children-in-law (Dutheil, 2001; Bracke et al., 2008; Willemé, 2010; Haberkern, Szydlik, 2010). It is most commonly women who provide caregiving for older people, especially when the level of care required is high (Gimbert, Malochet, 2012; Bocquet et al., 1997; Dutheil, 2001; Deboosere et al., 2006; Bracke et al., 2008; Fontaine, 2009; Bonnet et al., 2011). When men provide care for older people they generally do not carry out the same tasks as women caregivers do (Bocquet et al., 1997). While the women most often will take care of personal care and domestic tasks, the job of managing the budget and advocating for the patient's rights, for example, more often will be carried out by the men (Dutheil, 2001; Ravaud, Ville, 2003; Gaymu, 2012). Deboosere et al. (2006) found that the distribution of tasks varies according to type of household: men and women tend to participate equally in caregiving tasks when the older person lives with them at home, but if the patient lives elsewhere, it is more frequently women who will provide the care. Care provided from outside the patient's home presumably tends to be children - especially daughters - caring for their parents (Deboosere et al., 2006).

Some studies have also concluded that level of career involvement of caregivers can also account for differences between individuals in terms of profferment of care, although the link between these two variables, and what this means, remains unclear (Fontaine, 2009). Some empirical stud-

11. All quotations in this text have been translated in English by the authors. 
ies have in fact had contradictory results. Some authors, for example, affirm that people inactive in the formal workforce are more involved in caregiving activities, especially if the need for care is frequent (that is, more than twice per day) (Dutheil, 2001; Deboosere et al., 2006; Crespo, 2006; Henz, 2006). For some of these authors, this is because of voluntary abandonment of employment in order to fully dedicate oneself to caregiving activities. Other studies have concluded that level of care impacts on the relationship between caregiving activities and work opportunities. Those offering intensive levels of care are less likely to be involved in a career while those whose level of care is less intensive are more likely to be (Carmichael, Charles, 1998; Fontaine, 2009).

Be it as it may, being a caregiver involves a major investment in time, energy and emotion. Caregiving has consequences - physical, psychological, emotional, but also economic, professional and social - which taken together can be termed the «burden» of caregiving. On this point most authors are in general agreement. These willing caregivers suffer physically as well as psychologically, and even more so in cases of dementia where the behaviour and mood of older people are affected (Boutoleau-Bretonnière, Vercelletto, 2009). Still, caregiving can be rewarding (Gimbert, Malochet, 2012), and the investment of family caregivers at the career, family and personal level can be considerable. Career involvement, when this is an option, can often be a way of combating feelings of isolation, entrapment and withdrawal associated with caring for an older parent (Campéon et al., 2012). Caregiving responsibilities also mean a whole string of concessions at the family level (such as rearranging daily routines) whereby the caregiver may have difficulty in setting boundaries. The desire to keep things running well on all levels (career, family, helpers) exposes them to a variety of forms of pressure, exhaustion, stress and fatigue (Campéon et al., 2012).

In Belgium, changes to legislation were recently implemented in recognition of caregivers. This is an important first step toward the establishment of policies in their favour. The law in question was published in the Moniteur Belge on June 6, 2014, defining the family caregiver for a highly dependent person as «that person who renders regular or continuous assistance and support to the person being helped» (Art. 3, our emphasis). This same law defines the notions of assistance and support as «any investment in time on the psychological, social or moral plane and on the physical and material plane that has repercussions in terms of the career or family situation of the family caregiver» (Art. 2, No. 3). The assistance or support rendered must be continuous (lasting over time - Art. 2, No. 4 ) and regular (shaped by the cyclical progression of the disease or the 
development of dependency - Art. 2, No. 5), while at the same time taking into account the choices and desires of the person being helped (Art. 2, No. 6). The status of caregiver is granted under a number of conditions: the caregiver must have reached the age of majority (Art. 3, Sec. 2, No. 1), «must have developed a close or trusting, emotional or geographic relationship with the person being helped» (Art. 3, Sec. 2, No. 2), «must proffer the support or help for non-professional purposes, free of charge and with professional support» (Art. 3, Sec. 3, No. 1), and respect the desires of the person being helped (Art. 3, Sec. 3, No. 2). Finally, the law allows for the family caregiver to seek provisional recognition of their informal role from their public health provider.

While the adoption of this law will not result in major concrete changes for caregivers, it does make Belgium one of the few countries where caregivers are given legal recognition. Belgium must now establish a set of social rights to provide caregivers with protection and allow them if need to maintain their employment and access to social security, as well as receive physical and psychological support (ASBL Aidants proches ${ }^{12}$ ).

These recent changes were introduced at the level of Belgium, even if Flanders was a step ahead of the other regions of the country. As part of a 1999 decree, this region in the North of the country has set up a system of dependency insurance, the «Vlaamse Zorgverzekering» which, on the basis of individual annual contributions, could be used for non-medical aids provided to dependent persons, including those provided by the family circle (Karakaya, 2010; Masuy, 2010).

\section{Ageing and Retirement}

Just as important as these issues of health and care are those of pension and employment for older people. Growth rates for the population 65 years old and over, which can be predicted by the continuing rise in life expectancy and the baby-boomer generation reaching the 65-year-old mark, will peak in the European Union (EU) over the first half of the twenty-first century, reaching near-stagnation by 2050 in most EU countries. This raises the issue of the long-term financial viability of the retirement regime in its current form.

12. URL: www.aidants-proches.be/fr/loi-aidants-proches. 


\section{Belgium's Pension System}

The retirement pension branch of a social security system is often described as being built on three pillars. In Belgium, as in other EU countries, the first pillar is the statutory pension scheme, which will be described in the following section. The other two pillars are complementary pension structures that are optional. The second pillar is that of financial instruments (pension plans, collective insurance schemes) set up by companies or industry sectors that allow for additional pension payments to be made to workers after they retire. The third pillar is that of individual pension plans (e.g. retirement savings, life insurance) set up in view of accumulating capital to provide additional income upon retirement. The latter two pillars are buttressed by tax breaks offered by the government. In terms of the issue of the impact of ageing on the pension system, it is the impact on the first pillar that is at stake, that of the statutory pension scheme.

\section{History and Overview}

The statutory pension plan for salaried workers, in its current form as a redistributive pay-as-you-go pension system, was established in 1955 for labourers and in 1957 for salaried workers (previously it had been a system based on personal savings). This pension plan recognises overall work history and is designed to guarantee a decent quality of life for workers retiring from work. It is a compulsory social insurance system financed by workers' contributions drawn from their incomes, privatesector employers and government subsidies. The system provides a guarantee against loss of income due to «inability to work due to age» (Sanderson et al., 2015; Vanthemshe, 1994). This «inability to work» is made concrete by the application of a fixed retirement age, which since 2016 has been 65 years for both women and men. The worker qualifies for a full pension if they were active in the workforce for 45 years. ${ }^{13}$ Any worker having made contributions to the plan throughout their working life qualifies for a pension to replace their salary once they have reached official retirement age. The Belgian system, like that of other European

13. Up until 2016 an early retirement pension could be granted to individuals 60 years old with a 35 -year working history. 
countries, works by redistribution: contributions made by today's workers are used to pay annual pensions for those already retired (Conférence nationale des pensions, 2010). ${ }^{14}$

FIGURE 17 Life expectancy at age 65, EU, 2015

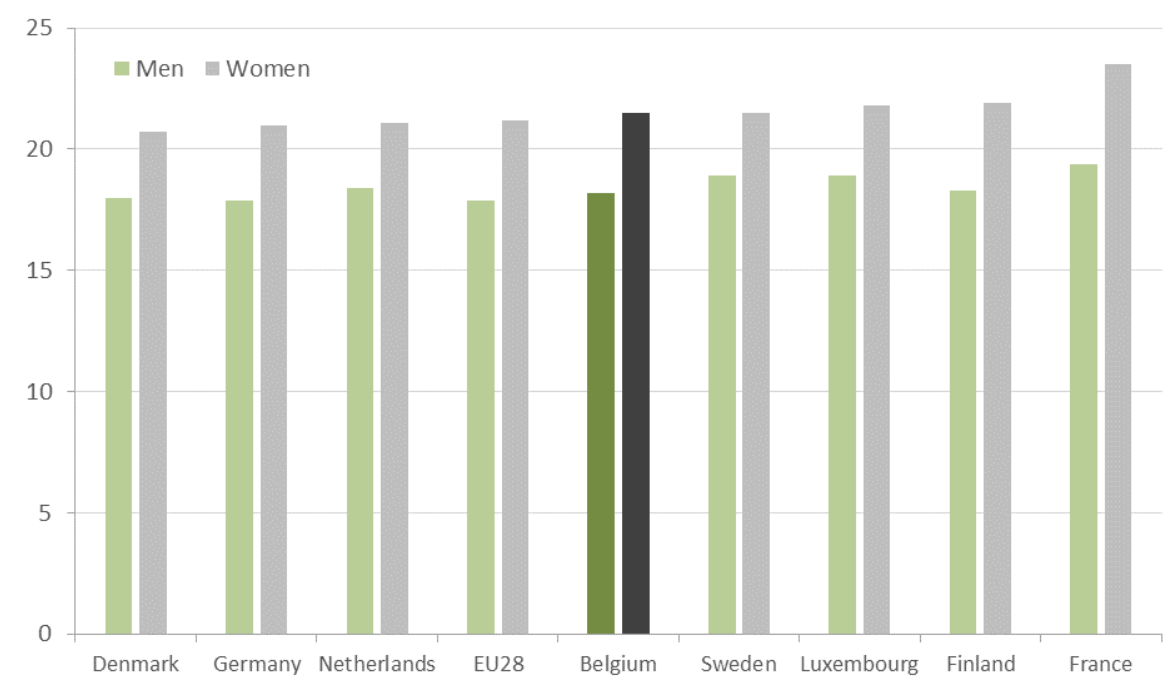

Source: Eurostat.

Belgium's pension plan was set up in the period after the Second World War, when Western Europe was experiencing strong economic growth. Life expectancy at birth in 1955 was 65.9 for men and 71.2 for women. In 2015 life expectancy at birth for men and women was 78.6 and 83.2 respectively, an increase of about 12 years over a period 60 years. In terms of life expectancy at 65 years - the age at which pension payments may, in principle, begin - the graph in Figure 17 shows that for all $28 \mathrm{EU}$ countries together actual average lifespan after 65 years is 17.9 years for men and 21.2 years for women, with the Belgian figures close to this at 18.2 and 21.5 respectively, or an average of about 20 years of life after the legal retirement age. For comparison purposes, life expectancy at 60 years, currently 21.9 years for men and 25.4 for women (Statbel, 201515), was at the end of the 1940s 15.4 and 17.4 years respectively (Chasteland, 1960), an increase of 6.5 years for men and 8 years for women.

14. The system thus encourages an intergenerational social contract.

15. https://statbel.fgov.be/fr/themes/population/mortalite-et-esperance-de-vie/ tables-de-mortalite-et-esperance-de-vie\#figures (exact ages). 


\section{Budgetary expenditure on pension scheme financing}

Political and social systems must adjust on numerous levels in the face of demographic change. Even from a purely financial point of view, an ageing population translates into long-term increases in social spending. Belgium's Study Committee on Ageing (CEV) regularly reviews the budgetary projections related to ageing for 2040-2060, based on a set of demographic, socioeconomic and macroeconomic projections as well as on a series of hypotheses that take into account trends in terms of social policies and reforms implemented by the country's governing bodies. In 2015 budgetary expenditure related to ageing was $25.3 \%$ of the GDP (Comite d'étude sur le vieillissement, 2016), that is, over 103 billion euros. This figure includes two major components: pension payments $(10.4 \%$ of the GDP) and health-care costs (8.0\% of the GDP). Thus in 2015 the amount Belgium spent on pensions was 42 billion euros.

It is projected that budgetary expenditure on ageing will reach $28.2 \%$ of the GDP in 2040 and diminish slightly thereafter to $27.6 \%$ of the GDP in 2060. The pension scheme component of this cost will also rise, to about $12.7 \%$ of the GDP in 2040 and 2060 . It goes without saying that, especially in a period of post-economic crisis, the growth in the proportion of the budget spent on ageing, and on pension payments in particular, will become a major strain on the budget (as it will for social spending in other areas). What is more, these projections are based on an average economic performance. For example, an increase in productivity of $1.5 \%$, which at a quarter - or half-point lower would mean an even greater proportion of the GDP spent on the long-term effects of population ageing.

\section{Possible steps to take}

Measures might be taken that do not pose any fundamental challenge to the first pillar, such as increasing worker contribution levels or decreasing pension allowances, but these would not be popular options. The former, which highlights the intergenerational aspect of the system, would not be easily accepted by the working population whose contributions finance the pensions of those already retired. The latter would already de facto be in effect if pensions ceased to be inflation-adjusted.

Other resources may also be tapped into to finance pension plan payments. In Belgium in 2001, the government set up an Ageing Fund in order to finance increased expenditure on pension payments between 2010 and 2030. This fund was to be drawn from public funding sources such as 
budgetary and social security surpluses, non-fiscal sources and earnings on fund investments. However, it was only in 2006 that there was a budgetary surplus and 176 million euros were able to be deposited into the fund; prior to that it had been funded purely from non-fiscal revenue. Since 2007 there has been no more funding from these two sources. Over 15 years only 16 billion euros were collected, or the equivalent of half a year of pension payments. This fund thus did not meet its objective of providing short-term mitigation for the increasing share of the GDP spent on pension payments. In May 2016 the government decided to wind up the fund, and this went into effect on January 1, 2017 (Conférence nationale des pensions, 2010; Itinera Institute, 2010).

\section{A Longer Working Life?}

\section{Retirement age}

Pushing back the legal retirement age and/or lengthening the contribution period for workers are key measures that have been taken by European governments in response to demographic ageing. The result is an increase in the number of workers, a decrease in the number of retirees, and for those who stop working before the legal retirement age, a decrease in pension allowances.

In Belgium the pension scheme that was put into place in the 1950s set the legal retirement age at 65 for men and 60 for women, the latter of which was raised to 65 in 1997. Span of working life was set at 45 years for men and 40 years for women, the latter raised to 45 years in 1997. Workers may also take early retirement up to 5 years before the legal retirement age (Sanderson, 2014). In 2005, in recognition of the intergenerational solidarity pact, access to early retirement pensions was limited in order to incite the employed and the self-employed to work right up to the legal retirement age.

Although the legal retirement age was 65 until 2016, a graph of the average retirement age between 1970 and 2014 (Figure 18) shows that at the EU level this indicator was gradually decreasing until the start of the twenty-first century, going from 68 years in 1970 down to 61.4 years by 2001 , and then rising slightly afterwards to 62.9 years in 2014. Through all periods, Belgium's average retirement age is among the lowest of the EU countries that appear in this graph. 
FigURE 18 Mean age at retirement for men in various EU countries (1970-2014)

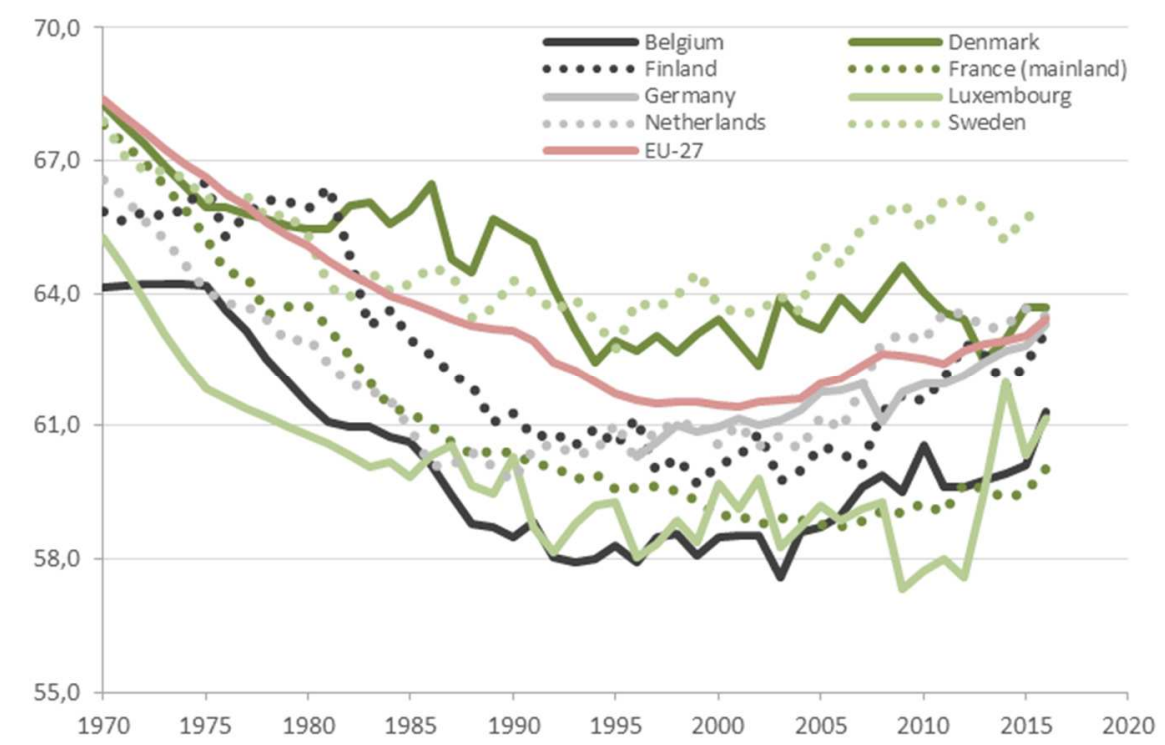

Source: OECD.

A workforce overlooked: 55-64-year-olds

The pension and retirement system touches upon the general issue of end of career, to which today is applied a series of measures for a smooth transition from employment to retirement. There is often a gap between the legal age for access to a pension and the age at which one actually leaves the employment market owing to the implementation of provisions for early retirement since the second half of the twentieth century (Burnay, 2011; Sanderson et al., 2015):

«...in the 1970s and 1980s, all European countries were in full-blown economic crisis. Drastic industry-restructuring programmes caused unemployment to soar. Public policies, such as those in Belgium, were designed to give the young unemployed the advantage over older workers (...). Workers 50 years of age and over were encouraged by the government to leave the work force through early retirement, unemployment, inability to work and taking sabbaticals. (...) the main objective of these measures was to smooth the way for employment for the young through the trimming away of older workers» (Burnay, 2011, p. 72).

This early withdrawal from the employment market has resulted in underemployment among 55-64-year-olds: in Belgium, the employment rate for those 20-64 years old is $67.7 \%$, but only $45.4 \%$ for those $55-64$ years old (data from Eurostat). While it is true that the employment rate for 55-64-year-olds in Belgium has been increasing since the late 1990s, 
it is well below rates in other European countries such as Denmark (67.8\%), Germany (68.6\%) and Sweden (75.5\%) (Figure 19).

FiguRE 19 Employment rate for persons aged 55-64 (men and women) for various EU countries

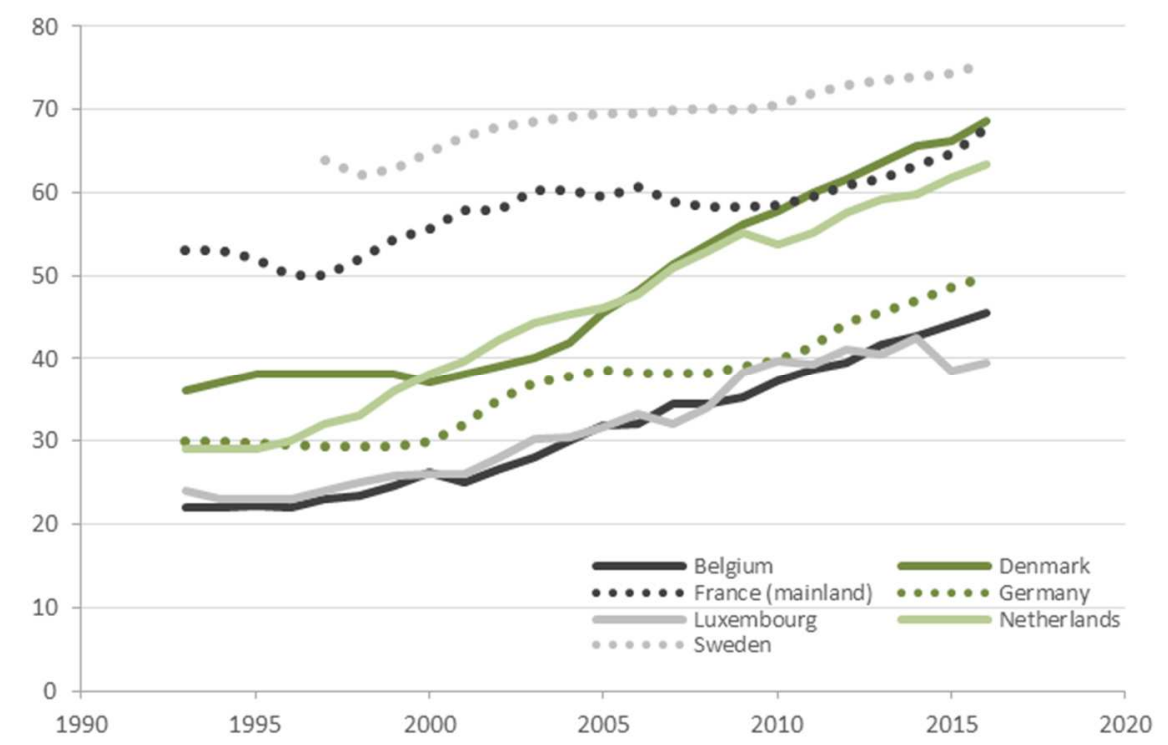

Source: Eurostat.

Even if Deboosere and Vandenheede (2015) argue that earlier retirement than before could increase life expectancy, a hypothesis that still has to be confirmed, attempts have been made in Europe to bring the employment rate for older workers back up, for example the Europe 2020 programme (Albanese, Cockx, 2015). Such programmes come up against many obstacles, including stereotypes about older workers, their frequent desire to leave the employment market before the legal retirement age, and the deterioration in working conditions, which increasingly «render career paths more vulnerable, especially through an increasing risk of developing health problems at end of career» (Burnay, 2011, p. 72).

Negative stereotypes about older workers are well entrenched. Lack of vigour, lower productivity, inability or lack of interest in using technology, resistance to change and modernisation: these examples point to the high level of antipathy toward these workers (Burnay, 2011). Even where their qualities are recognised (experience, sense of responsibility, selfsufficiency), it can be difficult to get to manage a company environment 
that is intergenerational (Burnay, 2011). Still, in an experiment carried out by BMW where only workers 50 years of age or older were assigned to an assembly line, productivity, after a brief initial dip, was maintained at the same level as other assembly lines, with only a slight ergonomic tweaks ${ }^{16}$ needed to work stations (The Economist, 2010).

Belgium, along with neighbouring countries, endorses the objectives set by the Europe 2020 strategy, whose overall goal is to «ensure high levels of employment, productivity and social cohesion» (SPF Emploi, 2017). As part of this, Belgium has committed to promoting employment and achieving, by 2020, an employment rate of 75\% for 20-64-year-olds (SPF Emploi, 2017). The 55-64-year-old group, whose employment rates are much lower than those of other age groups, is seen as constituting a worker pool that could be remobilised as part of efforts to attain the objectives of Europe 2020. Earlier Belgium had already adopted its Intergenerational Solidarity Pact (2005) in order to promote the employment of older workers. The main policies of this pact «consist in a reduction in employers' social security contributions, several reforms intending to discourage access to early retirement, an easier access to working time reduction with (partial) wage compensation, and a pension bonus» (Dejemeppe et al., 2015, p. 2). Studies have shown in retrospect that these measures have not been very effective (Albanese, Cockx, 2015; Dejemeppe et al., 2015). Dejemeppe et al. (2015) in particular conclude that these measures had very little impact on the employment rate for older workers, and that this has been to the detriment of younger workers. Pension reform, in place since 2011, makes it more difficult to meet the conditions for early retirement (including tightening up on requirements in terms of age and length of career), career sabbaticals and so on. In the long term, the goal is to increase the legal retirement age to 67 years old after 2030 .

If such efforts to deter workers from taking early retirement and to increase incentives to remain in the work force have not been very effective, in Finland a proactive policy aimed at people 45 years old or more has increased the employment rate for this group. A five-year plan in effect between 1998 and 2002 involving all the relevant ministries and based on the slogan «Experience is a source of wealth of our nation» targeted both the offer and demand sides of the job coin. In terms of offer, in order to convince those 45 years old or more to stay on the job market,

16. There were a number of adjustments made (70), but they were all relatively minor, e.g., magnifying glasses, adjustable tables, new chairs, custom footwear. 
measures were taken to improve working conditions and access to horizontal job transfers. In terms of demand, consultants were deployed to companies to help them deal with age-related issues in career-path management; this was followed up with support for companies to set up onthe-job training programmes for older workers. This series of measures addressing late-career work trajectories resulted in an increase in the employment rate for 55-59-year-olds from 51\% in 1998 to $63 \%$ in 2002 (Guillemard, 2004).

\section{Future Prospects}

In addition to delaying the age of retirement, other solutions have been proposed. One idea that comes up frequently is that of transitioning to a pre-funded pension system (De La Croix, Pestieau, 2007). Currently the Belgium pension system, based on worker contributions, is a redistributive pay-as-you-go pension system: the contributions of those currently in the work force serve to finance pension payments for those already retired. In a pre-funded pension system workers save for their own retirement. Most pension schemes in Europe are built on redistribution (Lamy, 2013) even if the principle of a partial pre-funded system is on the rise and found nearly everywhere. These pre-funded systems can be in the private or public domain. In 1999 France set up a public pre-funded scheme while Germany set up a private one. In Belgium, the Ageing Fund set up in 2001 was also a public scheme. Although it did not fulfill its objectives as hoped, pre-funded systems began to be developed in parallel: group insurance schemes (employer - or employee-based - second pillar) and life insurance/personal pre-funded pension plans (supported by governmental measures - third pillar).

The model currently in favour includes all three pillars, combining a redistribution scheme with pre-funded scheme (making sure to encourage the latter) while ensuring that the redistributive pay-as-you-go system guarantees an income for those who cannot depend on pre-funded system (De La Croix, Pestieau, 2007). 


\section{Conclusions}

The many ramifications of ageing means that ageing is often seen as an encumbrance...

Today's phenomenon of demographic ageing in European countries is a consequence of the demographic transition. It is usually attributed to the pushing back of mortality to older ages, yet it is due just as much to the decline in fertility from the nineteenth century, of which Belgium is an example. As this «révolution grise» has become increasingly visible since the 1970s, it has been accompanied by a host of messages, stereotypes and prejudices (Guérin, Pijoan, 2009; Chaunu, Suffert, 1976). Our research has revealed two aspects to ageing: a positive one signaling the victory of life over death, and a negative one stigmatising the degeneration and loss of autonomy that inevitably takes place as one ages.

There are indeed many implications to ageing. From a strictly demographic point of view, the surge in over 60s and especially over 80 s comes along with a transformation in the population profile. Ageing is often viewed as as a female phenomenon (Gaymu, 2009), and if women have a longer life expectancy, their gain is more quantitative than qualitative, as seen in changes in healthy life expectancy.

The different age groups do not evolve equally, one consequence of which is the phenomenon of ageing within ageing, with the nonagenarian and centenarian group growing faster than other groups. With death taking place at ever older ages, the chance of experiencing health problems has also risen. If today's health-care systems are vitally important in helping older people remain at home for longer, something which many of them want (Guyot, Marquet, 2017), we have focused on the role of the family caregiver, a vital facet of health-care systems for the old. Even the daily company that a family caregiver provides means that they play an essential role in the lives of the aged, but this comes with consequences, captured by the concept of the carer bearing a constant «burden».

The question of ageing also has numerous economic implications, especially in terms of the resilience of the social security system. The redistributive pay-as-you-go pension system that has dominated regimes thus far is progressively being caught up by the private pre-funded pension 
system that aims to guarantee a sufficient income upon retirement. ${ }^{17}$ The attainment of retirement age of baby boomers poses challenges to the current system which manifestly will require major reforms. One of these reforms is the delaying of the legal retirement age in Belgium and other European countries, in the aim of maximising the number of workers contributing into the pension fund and minimising the number of people drawing from that fund. This objective butts up against the reality that 55-64-year-olds have a low employment rate and that measures taken so far to keep this group active in the job market have been ineffective.

\section{... but thinking about ageing only from the angle \\ of "solutions» obscures the opportunities it brings}

While the consequences of ageing are often presented as «adverse» for Western societies, it must be remembered that ageing also brings with it a number of opportunities. Strictly speaking, the ageing of populations indirectly represents humanity's triumph over life and death, its ability to push the limits of human longevity. It is nonetheless true that this triumph has major consequences (in particular the tension between quantity and quality of life). Ageing is also often considered solely from the point of view of economic transfers; underpinning the debates about the financing of pensions and health-care systems is the more general question of the economic costs of ageing. But older people are not just the aged who spend extra years of their life in poor health or highly vulnerable to financial instability; they are also individuals who leave the work force at 60 to 65 years old with many healthy years ahead of them, sometimes with considerable socioeconomic clout (having paid off their mortgage, for example) and able to participate in an entire economy built around their age group, and who play a central role in their family support networks (at 65-70 years old it is perfectly possible to be simultaneously a «child», a parent and a grandparent). This upending of how ageing is viewed is in large part due to the work of Michel Loriaux, who in 1986 began to reconsider the "révolution grise» in a new light (Loriaux et al., 1990) while others were still advocating the idea of a "peste blanche» (Chaunu, Suffert, 1976) and casting this group in a very negative light (Minc, 1987). In his reconsideration of ageing, Loriaux proposed viewing

17. One issue is that such private mechanisms risk causing increased social inequality according to each person's individual ability to save for their own retirement through their working life. 
ageing as intergenerational exchange rather than as a dynamic of opposition (Loriaux, 1995).

What if demographic solutions for population ageing still had to be found?

From a strictly demographic point of view, the ageing population is due to a decline in fertility coupled with a lengthening lifespan. One of the consequences of this juxtaposition is an increase in the relative proportion of older people and a decrease in that of the young, but also of the working-age population. According to this point of view, three paths may be taken to «counter» the effects of ageing: reducing longevity, increasing fertility and expanding the working population through increased immigration. While the idea of reducing longevity is fundamentally disrespectful of human life, the other two options merit examination.

At first glance the most obvious option is to address the issue of births. Increasing the fertility rate (the average number of children per woman) should translate into an increase in births, and thus in the numbers at the bottom of the age pyramid. It would, however, be necessary to wait 20 to 25 years before this change were to begin to have an effect on the working-age population (the time for the children to grow up, gain their qualifications and enter the workforce). In the meantime this cohort would be an additional strain on society (Vincent, 2016). In addition, a rise in the fertility rate would represent a complete reversal of trends in this area. Currently the average number of children per woman in Belgium is 1.8 (Cytise/RN-DGS). Various authors, including Lesthaeghe (2011), have shown that Europe has entered what might be called a second demographic transition, characterised by very low fertility levels and the rise of the phenomenon of the only child. This socio-cultural context is not very conducive to increasing fertility, and researchers have even examined the emergence of new types of families such as the childless family (Debest, 2013). The idea of raising fertility is all the less plausible because in order for such a rise to have a structural effect on the workforce it would have to be rapid, strong (some researchers even suggest an average of three children per woman (de Foucauld, Fraisse, 1996)) and especially, enduring (such that the effect is long-lasting and does not transform into a «baby-boom» type of scenario where the rise in fertility is followed by a drop, eventually leading to a «oldie-boom»).

Increasing immigration can also come across as an easy solution in a time of major population migrations. In 2000, the United Nations determined that, in 2050, Europe would require an annual total of 1'400'000 immigrants in order to maintain the ratio between working-age and non- 
working-age populations that year. Although the hypotheses on which such models are built may be subject to critique (Léridon, 2000), they do serve the purpose of highlighting the absurdity of such a solution: not only would very high annual influxes of immigrants be required, so would a major change in attitude on the part of host populations, as evidenced by the political debate over the current migrant crisis.

As Léridon (2000) has pointed out, trying to find «solutions» to ageing may be missing the point. At the end of the 1990s the OECD proposed a new concept, that of active ageing, implying a shift in paradigm from viewing ageing as a bad thing to viewing it as an opportunity (Guillemard, 2013). This new paradigm should lead to a rejigging of the life stages. The three-pronged approach of qualifications-work-retirement would give way to a more flexible model allowing the coming and going between these phases according to family stages and individual choice. Unfortunately, current policies are mostly focused on lengthening working life and removing the possibility of retiring early from the job market (Guillemard, 2013). Still, the latter remains the most promising avenue, all the more because it suggests a rethinking of society and of intergenerational solidarity (Tourniaire-Kashari, 2014) and addresses the need to take a new look at ages and thresholds, in light of the fact that the increase in longevity (including in good health) completely changed the picture from the end of the nineteenth century, when Bismarck «invented» retirement for all (Vanthemsche, 1994) and in Belgium the need to provide financial allowances for workers in the final years of life was being considered (Sanderson, 2014).

\section{References}

Adveev A., Eremenko T., Festy P., Gaymu J., Le Bouteillec N., Springer S. (2011), «Populations et tendances démographiques des pays européens (1980-2010)», Population, 66 (1), pp. 9-133, https://doi.org/10.3917/popu.1101.0009.

Albanese A., Cockx B. (2015), Permanent Wage Cost Subsidies for Older Workers. An Effective Tool for Increasing Working Time and Postponing Early retirement?, Discussion Paper, Institut de Recherches Économiques et Sociales de I'Université catholique de Louvain (IRES), $43 \mathrm{p}$.

Alzheimer Europe (2013), «2013: National Policies Covering the Care and Support of People with Dementia and their Carers», Dementia in Europe. Yearbook 2013, 251 p. 
ANKRI J. (2009), «Prévalence, incidence et facteurs de risque de la maladie d'Alzheimer», Gérontologie et Société, 128-129, pp. 129-141, https://doi.org/10.3917/gs. 128.0129.

Bocquet H., GRAND A., CLÉment S. (1997), «L'aide informelle aux personnes âgées vivant à domicile», J.-C. HENRARD (coord.), Dossier Santé publique \& grand âge. Actualité et Dossier en Santé Publique, 20, Haut Comité de Santé Publique, pp. 27-32.

Bonnet C., Cambois E., CASes C., Gaymu J. (2011), «La dépendance : aujourd'hui l'affaire des femmes, demain davantage celle des hommes ?», Population \& Sociétés, Institut National d'Études Démographiques, 483, 4 p.

Bopp M. (2013), «La multimorbidité chez les personnes de 50 ans et plus. Résultats basés sur l'enquête SHARE (Survey of Health, Ageing and Retirement)», OBSAN Bulletin, (4), $8 \mathrm{p}$.

Bopp M., Holzer B. M. (2012), «Prevalence of Multimorbidity in Switzerland - Definition and data sources», Praxis (Bern 1994), 101 (25), pp. 1'609-1'613.

BouRdelais P. (1989), "Vieillissement de la population ou artefact statistique ?», Gérontologie et Société, 49, pp. 22-32.

Bourguignon M., Eggerickx T., SANDerson J.-P. (2015), "Offre vs. Besoins de prise en charge chez les personnes âgées. Une typologie des communes wallonnes», Cahiers de Démographie Locale 2013/14, pp. 195-240.

Bourguignon M., EgGerickX T., SANDERSON J.-P. (2017), «Quels territoires de santé gérontologique pour repenser l'adéquation entre offre et besoins d'aides en Wallonie ?», Revue Francophone sur la Santé et les Territoires, pp. 1-23.

Boutoleau-Bretonnière C., Vercelletto M. (2009), «Fardeau de l'aidant dans la pathologie démentielle : lien avec les activités de la vie quotidienne et les troubles psycho-comportementaux», Psychologie \& NeuroPsychiatrie du vieillissement, 7 (1), Numéro spécial, pp. 15-20.

Bracke P., Christiaens W., Wauterickx N. (2008), "The Pivotal Role of Women in Informal Care», Journal of Family Issues, 29 (10), pp. 1'348-1'378.

Brée S., Eggerickx T., SANderson J.-P., Costa R. (2016), “Comparaison des données rétrospectives de fécondité dans les recensements en Belgique et les enquêtes Famille en France», Population, 71 (1), pp. 85-120, https://doi.org/10.3917/popu. 1601.0085 .

Bureau Fédéral du Plan, Direction générale Statistique (2016), Perspectives démographiques 2015-2060 Population, ménages et quotients de mortalité prospectifs, Mars, Bruxelles, $70 \mathrm{p}$.

BuRNAY N. (2011), "La cohabitation intergénérationnelle en entreprise : des stéréotypes prégnants à l'égard des séniors. Analyse de la situation belge», Communication et Organisation, 40, pp. 71-86, https://doi.org/10.4000/communicationorganisation.3543. 
CALot G., SARdon J.-P. (2000), «La mesure du vieillissement démographique», Espace, Populations, Sociétés, 3, pp. 475-481, https://doi.org/10.3406/espos.2000.1967.

CAmpéon A., Le Bihan B., Martin C. (2012), «La prise en charge des personnes âgées dépendantes en Europe : le vécu des aidants familiaux», Vie Sociale, 4, pp. 111-127, https://doi.org/10.3917/vsoc.124.0111.

Carmichael F., Charles S. (1998), "The Labour Market Costs of Community Care», Journal of Health Economics, 17, pp. 747-765, https://doi.org/10.1016/S0167-6296 (97)00036-2.

Charlot V., Guffens C. (2007), Où vivre entouré ? L'accueil des personnes âgées atteintes de démence dans les lieux de vie résidentiels collectifs, Fondation Roi Baudoin, Les Éditions Namuroises, Namur, 164 p.

CHASTELAND J.-C. (1960), «Évolution générale de la mortalité en Europe occidentale de 1900 à 1950», Population, 15 (1), pp. 59-88, https://doi.org/10.2307/1527240.

Chaunu P., Suffert G. (1976), La peste blanche : comment éviter le suicide de l'Occident, Paris, $263 \mathrm{p}$.

Comité d'étude sur le vieillissement (2016), Rapport annuel, Juillet, 69 p., www. plan.be/admin/uploaded/201607130830490.REP_CEVSCVV2016_11259_F.pdf.

Conférence Nationale des Pensions (2010), Consolider I'avenir des pensions, Rapport intermédiaire, Bruxelles.

Costa R., Eggerickx T., Rizzi E., SANderson J.-P. (2016), «Analyse spatiale et temporelle de la fécondité en Belgique : une approche communale», La fécondité : représentation, causalité, prospective, CUDEP, pp. 102-119.

CRESPO L. (2006), Caring for Parents and Employment Status of European Mid-Life Women, Working Paper, Madrid, CEMFI (Centro De Estudios Monetarios y Financieros), $55 \mathrm{p}$.

de Foucauld J. B., Fraisse R. (eds) (1996), La France en prospectives, Paris, 400 p.

De LA Croix D., Pestiaux P. (2007), "Réformer le système des retraites Belge», Regards économiques, 51, pp. 1-12.

Debest C. (2013), «Quand les 'sans-enfant volontaires' questionnent les rôles parentaux contemporains», Annales de Démographie Historique, 125 (1), pp. 119-139, https://doi.org/10.3917/adh.125.0119.

Deboosere P., Demarest S., lorant V., Miermans P.-J., Portet M.-I., Van Oyen H. (2006), Santé et soins informels, Enquête socio-économique 2001, Monographie, SPF Économie, P. M. E., Classes Mmoyennes et Énergie, Direction Générale Statistique et Information Économique, $191 \mathrm{p}$.

Deboosere P., Vandenheede H., (2015) «Reversing the Malthusian Paradigm on Retirement Age», Revue Quetelet/Quetelet Journal, 3 (1), pp.75-95, https://doi.org/10.14428/rqj2015.03.01.03. 
Debuisson M., Eggerickx T., Hermia J.-P., Poulain M. (2000), L'évolution de la population. L'âge et le sexe, Institut National de Statistique, Bruxelles, $168 \mathrm{p}$.

Dejemeppe M., SMith C., VAN DeR Linden B. (2015), Did the Intergenerational Solidarity Pact Increase the Employment Rate of Older Workers in Belgium? A Macro-Economic Evaluation, Discussion Paper, Institut de Recherches Économiques et Sociales de I'Université catholique de Louvain (IRES), $36 \mathrm{p}$.

DeVolder P., MARÉChal X. (2007), «Réforme du régime belge de pension légale basée sur la longévité», Belgian Actuarial Bulletin, 7, pp. 34-38.

DutheIL N. (2001), "Les aides et les aidants des personnes âgées», Études et Résultats, 142, Direction de la recherche, des études, de l'évaluation et des statistiques (DREES), $12 \mathrm{p}$.

EggerickX T., Oris M., SANDerson J.-P., ViLPERT S. (2001), L'évolution de la population, l'âge et le sexe, Monographie 1 de l'Enquête socio-économique de 2001, DGSIE, Bruxelles, $230 \mathrm{p}$.

EggerickX T., TAButin D. (2002), "Le vieillissement démographique dans le monde. Historique, mécanismes et tendances», AIDELF, Vivre plus longtemps, avoir moins d'enfants : quelles implications ?, PUF, Paris, pp. 85-123.

Eurostat (2015), Population: Structure indicators, http://appsso.eurostat.ec.europa. eu/nui/show.do.

Feller E. (2005), Du vieillard au retraité. Histoire de la vieillesse en France (19001960), Histoire, cultures et sociétés, SeliArslan, Paris, 352 p.

FESTY P. (1979), La fécondité des pays occidentaux de 1870 à 1970, Paris, PUF.

FONTAINE R. (2009), «Aider un parent âgé se fait-il au détriment de l'emploi ?», Retraite et Société, 58, pp. 31-61.

GaYmu J. (2009), "Vieillir en Europe», Idées Économiques et Sociales, 157, pp. 27-33, https://doi.org/10.3917/idee.157.0027.

GAYMu J. (2012), La dépendance : des vécus différents pour les hommes et les femmes, Document internet, 6 p., consulté le 27/06/2013, www.wikiterritorial.cnfpt.fr/ xwiki/wiki/econnaissances/view/Questions-Cles/Ladependancedesvecusdifferents pourleshommesetfemmes\#HLesfemmes2Caujourd2019huilespiliersdelapriseencha rgedeladE9pendance.

Gimbert V., MAlochet G. (2012), "Quelles mesures de soutien aux aidants des personnes âgées dépendantes? Un tour d'horizon international», Vie sociale, 4, pp. 129-145.

GUÉRIN S., PIJOAN N. (2009), "Intégration ou exclusion des seniors, l'impact des représentations sociocognitives des décideurs : l'exemple des directeurs de maison de retraite», Management \& Avenir, 30 (10), pp. 107-126, https://doi.org/10.3917/mav. 030.0107. 
Guillemard A.-M. (2004), «L'emploi des seniors les enseignements de l'Europe du Nord et du Japon", Gérontologie et Société, 111, pp. 29-43, https://doi.org/10.3917/ gs.111.0029.

Guillemard A.-M. (2013), "Le vieillissement actif : enjeux, obstacles, limites : une perspective internationale», Retraite et Société, 65 (2), pp. 17-38.

GuYot J.-L., MARQUet J. (eds.) (2017), Le bien vieillir en Wallonie. Enjeux et prospective, Presses universitaires de Namur, Namur, $354 \mathrm{p}$.

HABerkern K., Szydlik M. (2010), "State Care Provision, Societal Opinion and Children's Care of Older Parents in 11 European Countries", Ageing and Society, 30 (2), pp. 299-323, https://doi.org/10.1017/S0144686X09990316.

HenraRd J.-C. (coord.) (1997), "Dossier Santé publique \& grand âge», Actualité et Dossier en Santé Publique, 20, Haut Comité de Santé Publique, 44 p.

Henz U. (2006), «Informal Caregiving at Working Age: Effects of Job Characteristics and Family Configuration», Journal of Marriage and Family, 68 (2), pp.411-429, https://doi.org/10.1111/j.1741-3737.2006.00261.x.

Itinera Institute (2010), Le petit livre rouge d'Itinera sur les pensions, Bruxelles.

LAMY M. (2013), "Les systèmes de retraite dans I'Union Européenne», Espace, Populations, Sociétés, 3, pp. 163-173, https://doi.org/10.4000/eps.5596.

LANNOYE F., LYPSZIC B. (2000), Le vieillissement en Belgique : données démographiques et implications économiques, Liège, Working papers du CREPP, 4.

LefèbVre M., Pestieau P., Ponthière G. (2014), «Mortalité différentielle et pauvreté par âge», Revue Française d'Économie, xxix (4), pp. 173-196, https://doi.org/10. 3917/rfe.144.0173.

LÉRIDON H. (2000), «Vieillissement démographique et migrations : quand les Nations Unies veulent remplir le tonneau des Danaïdes...», Population et Sociétés, 358, INED.

LeSthaEghe R. (2011), «The 'Second Demographic Transition': A Conceptual Map for the Understanding of Late Modern Demographic Developments in Fertility and Family Formation», Historical Social Research, 36, pp. 179-218.

LeSthaeghe R., SURKyn J. (2004), «Value Orientations and the Second Demographic Transition (SDT) in Northern, Western and Southern Europe: An Update», Demographic Research, Special Collection, 3, pp. 45-86.

LoRiaux M., Remy D., Vilquin E. (eds) (1990), Populations âgées et révolution grise. Les hommes et les sociétés face à leurs vieillissements. Chaire Quetelet 1986, Louvain-la-Neuve, $1118 \mathrm{p}$.

LORIAUX M. (1995), «Du vieillissement démographique à l'intégration des âges : la révolution de la géritude», Population, 50 (6), pp. 1 611-1 625.

MAsuY A. J. (2010), «Les politiques de soutien aux aidants proches en Belgique : un développement typiquement belge», Revue Belge de Sécurité Sociale, 1, pp. 59-80. 
MEsLÉ F. (2004), «Espérance de vie : un avantage féminin menacé ?», Population et Sociétés, 402 (4), pp. 1-4.

Minc A. (1987), La machine égalitaire, Grasset, 288 p.

MonNier A. (2006), Démographie contemporaine de l'Europe. Évolution, tendances, défis, Paris, Armand Colin, $416 \mathrm{p}$.

Ravaud J.-F., Ville I. (2003), «Les disparités de genre dans le repérage et la prise en charge des situations de handicap», Revue Française des Affaires Sociales, 1-2, pp. 225-253.

RÉRAT P. (2016), «Le retour des villes», Espace, Populations, Sociétés, 1, 20 p.

SANDERSON J.-P. (2013), «Partir ou rester ? Transformation du choix résidentiel en fin d'activité de 1970 à 2006 en Belgique», Espace Populations Sociétés, 3, pp. 119-133, https://doi.org/10.4000/eps.5576.

SANDERSON J.-P. (2014), "La réforme des retraites en question : le vieillissement démographique justifie-t-il de se limiter au recul de l'âge légal à la retraite ?», Revue Belge de Sécurité Sociale, 1, pp. 3-20.

SANDERSON J.-P., EgGERICKX T., Burnay N. (2015), «Vieillissement de la population et mise en place du système des retraites en Belgique», A. AdjAMAGBo, P. ANTOINE (eds), Démographie et politiques sociales, Actes du XVIle colloque, Ouagadougou, Novembre 2012, $18 \mathrm{p}$.

SARDON J.-P. (2004), «Évolution démographique récente des pays développés», Population, 59 (2), pp. 305-360.

Service Public Fédéral Emploi, Travail et Concertation sociale (2017), La stratégie européenne pour l'emploi, Publication en lige, www.emploi.belgique.be/defaultTab. aspx?id=15594.

The Economist (2010), «The Silver Tsunami. Business Will Have to Learn how to Manage an Ageing Workforce», The Economist, Business section, Schumpeter Column, February 6th.

TOURNIAIRE-KASHARI A. (2014), "Les enjeux du vieillissement actif et de la solidarité entre les générations dans l'Union européenne», Informations Sociales, 183 (3), pp. 116-124.

Valuin J. (2002), «Mortalité, sexe et genre», G. CASELLI, J. VALLIN, G. WUNSCH (eds), Démographie : analyse et synthèse, Tome III : Les déterminants de la mortalité, Éditions de l'INED, pp. 319-350.

VANDENBerghe V. (2010), «Peut-on se passer des préretraites et dispenses de recherche d'emploi pour les chômeurs âgés ?», Reflets et perspectives de la vie économique, 49, pp. 107-124.

Van der Heyden J., Charafeddine R. (eds) (2014), Enquête de santé 2013. Rapport 1 : Santé et bien-être, Résumé des principaux résultats, ISP-WIV, Bruxelles, 36 p., https://his.wiv-isp.be/fr/documents\%20partages/summ_hs_fr_2013.pdf. 
VANDRESSE M. (2017), «Le vieillissement de la population sous l'angle de l'âge prospectif. Un indicateur complémentaire», A. VANDENHOOFT, S. CARBONNELLE, T. EGGERICKX, V. Flohimont, S. PERELMAN (eds), Vieillissement et entraide. Quelles méthodes pour décrire et mesurer les enjeux ?, Namur, pp. 39-72.

VANTHEMSCHE G. (1994), La sécurité sociale. Les origines du système belge. Le présent face à son passé, Deboeck, Bruxelles, 200 p.

VINCENT P. (2016), "Vieillissement de la population, retraites et immigration», Population, 71 (2), pp. 349-380, https://doi.org/10.3917/popu.1602.0349.

WillemÉ P. (2010), The Belgian Long-Term Care System, Working Paper (7-10), Bruxelles, Bureau Fédéral du Plan, 28 p.

World Health Organization (2016), International Statistical Classification of Diseases and Related Health Problems 10th Revision, http://apps.who.int/classifications/ icd10/browse/2016/en. 